\title{
Ultrastructure of Synapses in the Mammalian Brain
}

\author{
Kristen M. Harris ${ }^{1}$ and Richard J. Weinberg ${ }^{2}$ \\ ${ }^{1}$ Center for Learning and Memory, Neurobiology Section, University of Texas, Austin, Texas 78712 \\ ${ }^{2}$ Department of Cell \& Developmental Biology, and Neuroscience Center, University of North Carolina, \\ Chapel Hill, North Carolina 27599 \\ Correspondence: kharris@mail.clm.utexas.edu; richard.weinberg@gmail.com
}

The morphology and molecular composition of synapses provide the structural basis for synaptic function. This article reviews the electron microscopy of excitatory synapses on dendritic spines, using data from rodent hippocampus, cerebral cortex, and cerebellar cortex. Excitatory synapses have a prominent postsynaptic density, in contrast with inhibitory synapses, which have less dense presynaptic or postsynaptic specializations and are usually found on the cell body or proximal dendritic shaft. Immunogold labeling shows that the presynaptic active zone provides a scaffold for key molecules involved in the release of neurotransmitter, whereas the postsynaptic density contains ligand-gated ionic channels, other receptors, and a complex network of signaling molecules. Delineating the structure and molecular organization of these axospinous synapses represents a crucial step toward understanding the mechanisms that underlie synaptic transmission and the dynamic modulation of neurotransmission associated with short- and long-term synaptic plasticity.

$T^{\mathrm{h}}$ he structural basis of information transfer between nerve cells remained obscure until the late 19th century, when neuroanatomists using newly developed silver stains identified axonal boutons that seemed to contact dendrites or dendritic spines of other neurons (Fig. 1) (Shepherd 1995; Guillery 2005). The term "synapse" (from the Greek "to clasp") was originally suggested to Sherrington by his friend A.W. Verrall, a Greek scholar. However, some still claimed a protoplasmic continuity between presynaptic and postsynaptic elements. This argument between "neuronal" and "reticular" theories was not finally resolved until the introduction of electron microscopy (EM), which en- abled direct visualization of the synapse and revealed a cleft separating the presynaptic axon from the postsynaptic dendrite (Fig. 1, inset) (De Robertis and Bennett 1955; Palay and Palade 1955).

Understanding the structure of synapses is a crucial first step in understanding their function. This article addresses the ultrastructure and subcellular composition of synapses in the mammalian brain, as defined by high-resolution electron microscopy (EM). Examples are drawn mainly from rodent hippocampus, cerebral cortex, and cerebellum. Gray (1959) identified two main categories of synapses: type I or asymmetric (later shown to be glutamatergic

Editors: Morgan Sheng, Bernardo Sabatini, and Thomas Südhof

Additional Perspectives on The Synapse available at www.cshperspectives.org

Copyright (C) 2012 Cold Spring Harbor Laboratory Press; all rights reserved; doi: 10.1101/cshperspect.a005587

Cite this article as Cold Spring Harb Perspect Biol 2012;4:a005587 
K.M. Harris and R.J. Weinberg

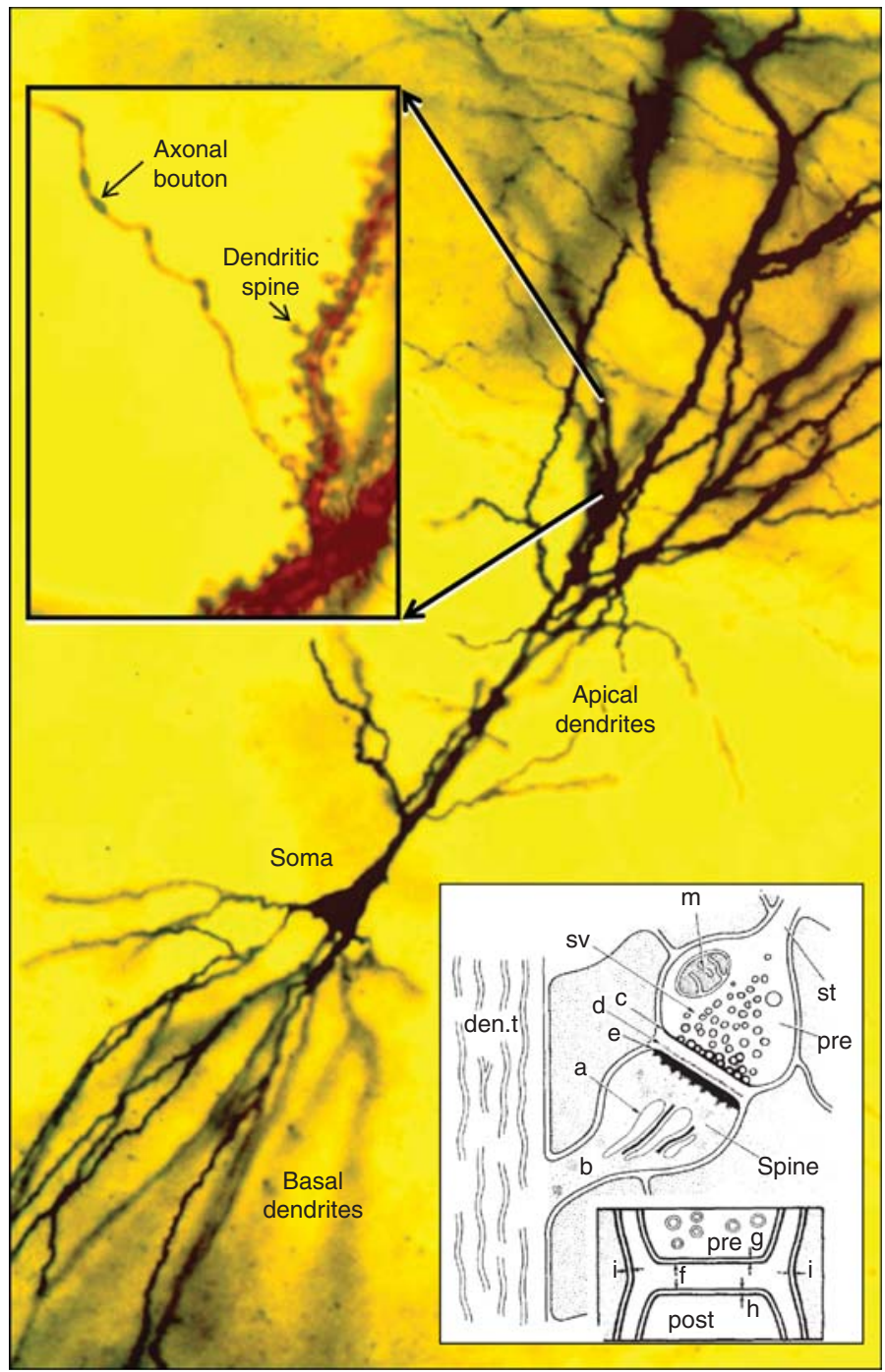

Figure 1. Golgi-impregnated pyramidal cell in hippocampal area CA1, showing the soma and apical and basal dendrites. (inset, left) Higher magnification shows an axon passing by dendritic spines protruding from the apical dendritic shaft. (inset, right) A drawing from the earliest EMs of dendritic spines: (a) spine apparatus; (b) spine neck; (c) presynaptic membrane; (den.t.) dendritic microtubules; (d) dense material in synaptic cleft; (e) postsynaptic membrane; (f) synaptic cleft; (g,h,i) plasma membranes of pre-, post-, and neighboring processes; (m) mitochondrion; (pre) presynaptic axons; (st) "stalk" of axon; (sv) synaptic vesicles. (Images are modified from Gray 1959 and Harris et al. 1980; reprinted, with permission, from Oxford University Press (C) 1959 and Elsevier (C) 1980, respectively.)

and excitatory), and type II or symmetric (later shown to be inhibitory). Here we focus mainly on the asymmetric synapses on dendritic spines. For contrast, some data are also presented from inhibitory and neuromodulatory synapses. Where possible, we integrate structural descriptions with discussion of key synaptic molecules. For additional description and images, see Peters et al. (1991) and online atlases at http://synapses.clm. utexas.edu/atlas/contents.stm, http://ccdb.ucsd. edu/index.shtm, and http://www.drjastrow. de/ EMAtlasE.html. 


\section{ORGANIZATION OF THE SYNAPTIC NEUROPIL}

Excitatory synapses are found mainly on dendrites and dendritic spines, whereas inhibitory synapses concentrate on the cell soma and axonal initial segment, with a sparse distribution along both spiny and nonspiny dendritic shafts. Dendrites, axons, and astroglial processes form a fine felt-like mesh — the neuropil-where most of the synaptic interactions occur. Serial-section electron micrographs from ultrathin $(\sim 50 \mathrm{~nm})$ sections of neuropil from the rat hippocampus illustrate dendrites, axons, and astroglial processes (Fig. 2A); within this complex neuropil are a large number of excitatory asymmetric synapses (Fig. 2B-D) and a smaller number of inhibitory symmetric synapses (Fig. 2E,F). This article describes synaptic structure in functional sequence from presynaptic axons to postsynaptic dendritic spines.

\section{PRESYNAPTIC COMPONENTS}

\section{Axonal Boutons}

The excitatory axospinous synapses in the stratum radiatum (s. radiatum) of hippocampal area CA1 are typical of synapses formed by the thin, often unmyelinated axons that predominate throughout the brain. Most of the presynaptic axons originate from CA3 pyramidal cells and synapse with spines extending from the apical dendrites of CA1 pyramidal cells. Individual axons weaving throughout the complex neuropil form presynaptic boutons that contain neurotransmitter-filled vesicles (Fig. 3A,B). The large majority ( $\sim 75 \%)$ of these vesicle-containing boutons make a single synaptic contact, $\sim 21 \%$ form multiple synapses, and $\sim 4 \%$ lack a postsynaptic partner (Shepherd and Harris 1998; Sorra et al. 2006). Under conditions of rapid synaptogenesis in the mature hippocampus, new postsynaptic partners synapse with existing presynaptic boutons, giving rise to more multisynaptic boutons and avoiding the need to generate presynaptic boutons de novo (Kirov et al. 1999, 2004; Yankova et al. 2001; Petraket al. 2005). It is not known whether multisynaptic boutons play a significant role during developmental synaptogenesis.
Other axons throughout the brain form distinct types of synapses. For example, the mossy fiber axons arising from granule cells of the dentate gyrus that terminate on the proximal dendrites of area CA3 pyramidal cells have very large presynaptic boutons, each synapsing with multiple dendritic spines (Fig. 3C). These boutons also form small thin protrusions that synapse on the shafts of nonspiny interneurons (Amaral and Dent 1981; Lawrence and McBain 2003). Axons in the cerebellar cortex form a variety of synapses (Palay and Chan-Palay 1974). Cerebellar granule cells give rise to a single parallel fiber, which makes axospinous synapses with numerous Purkinje cell dendritic spines; in contrast, a single climbing fiber (originating from the inferior olive) forms numerous synaptic boutons along the proximal dendritic shaft of a single Purkinje cell (Xu-Friedman et al. 2001). Specialized contacts on the dendrites of cerebellar granule cells are termed "synaptic glomeruli"; each glomerulus is characterized by an exceptionally large presynaptic bouton synapsing with multiple postsynaptic dendrites. The axonal varicosities of inhibitory symmetric synapses often make direct contacts with the surface of the cell soma, interspersed among glial processes (Fig. 3D,E) (Ledoux and Woolley 2005). For other examples of the remarkable diversity of presynaptic boutons, see http://synapses.clm.utexas.edu/atlas/1_6intro.stm.

\section{The Active Zone}

The active zone (AZ) is a specialized region on the presynaptic plasma membrane, where synaptic vesicles are docked and primed for release (Heuser and Reese 1977; Landis et al. 1988; Sudhof 1995). The AZ is aligned in registry with the postsynaptic density. In electron micrographs, it can be recognized by the increased electron density of the presynaptic membrane in this region. Associated with the AZ are cytoplasmic "dense projections," apparently organized into a presynaptic grid (Fig. 4A); the status of these structures is uncertain, perhaps because they are variable and sensitive to fixation and processing (Gray 1963; Pfenninger et al. 1972; Landis et al. 1988; Siksou et al. 2007). At some synapses (e.g., 
K.M. Harris and R.J. Weinberg
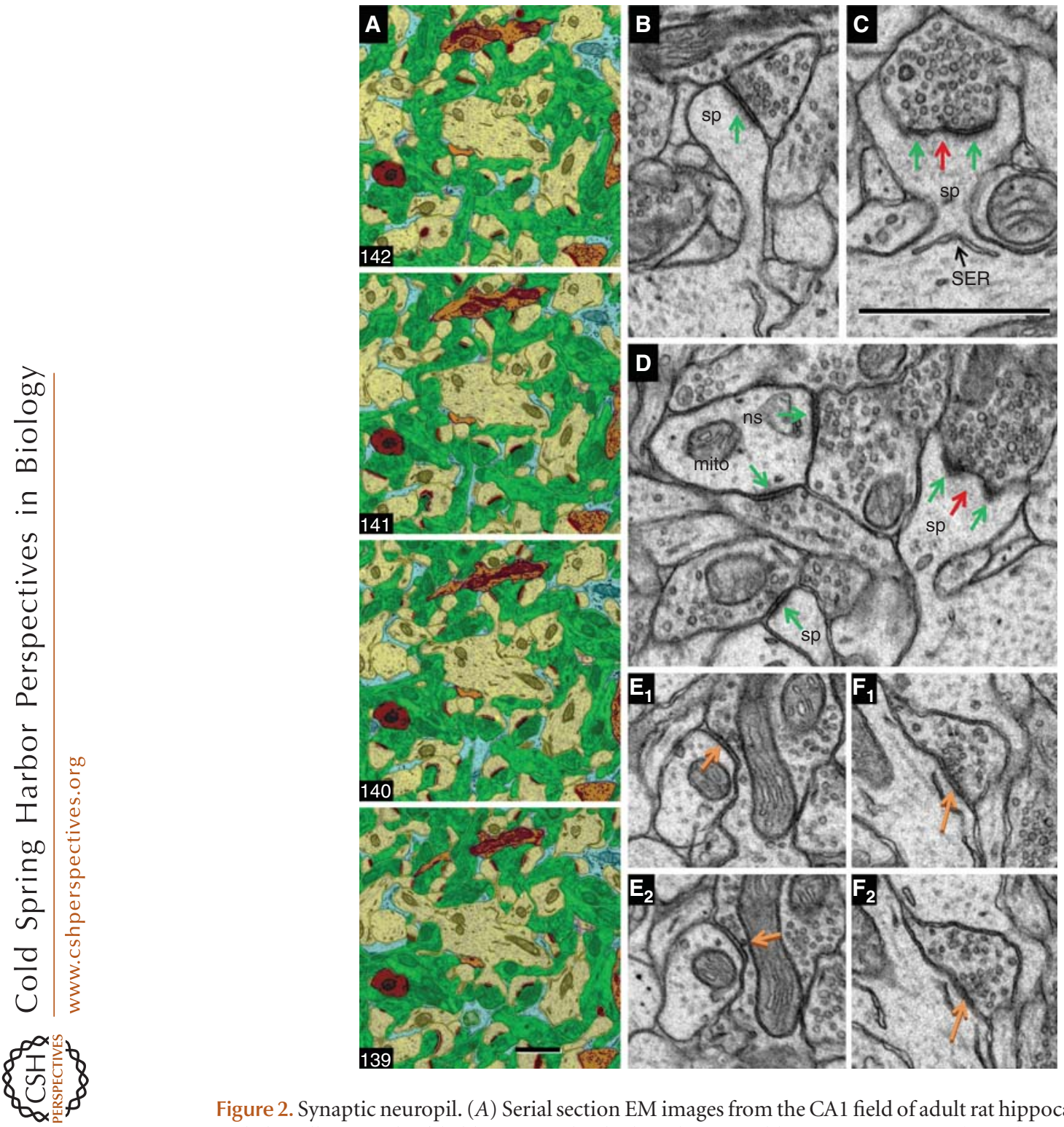

Figure 2. Synaptic neuropil. (A) Serial section EM images from the CA1 field of adult rat hippocampus are colorcoded to illustrate the felt-like neuropil, which is dominated by excitatory axons (green) and spiny dendrites (yellow). One nonspiny dendrite (brown, also NS in panel $D$ ) and pieces of four inhibitory axons (orange) are visible in these sections, typical of their sparse distribution in the neuropil. Several thin astroglial processes (light blue) interdigitate among the axons and dendrites. (B) Asymmetric synapse with a macular PSD (green arrow) on a medium-size dendritic spine (sp). (C) PSD (green arrows) perforated by an electron-lucent region (red arrow) on a large dendritic spine (sp) with some SER at its base. (D) Asymmetric synapses (green arrows) on the shaft of a nonspiny dendrite (ns) containing a mitochondrion (mito) have comparable thicknesses to the macular and perforated PSDs on dendritic spines in the same field. (E) Adjacent sections through a symmetric synapse (orange arrows) on a spiny dendritic shaft (the arrow in $E_{2}$ points to a presynaptic docked vesicle). $(F)$ Adjacent sections through another symmetric synapse (orange arrows) formed by the same axon as in $E$, but on a different spiny dendritic shaft. The $1-\mu \mathrm{m}$ scale bar in section 139 is for the neuropil series in $A$; the 1 - $\mu \mathrm{m}$ scale bar in $C$ is for panels $B-F$. 

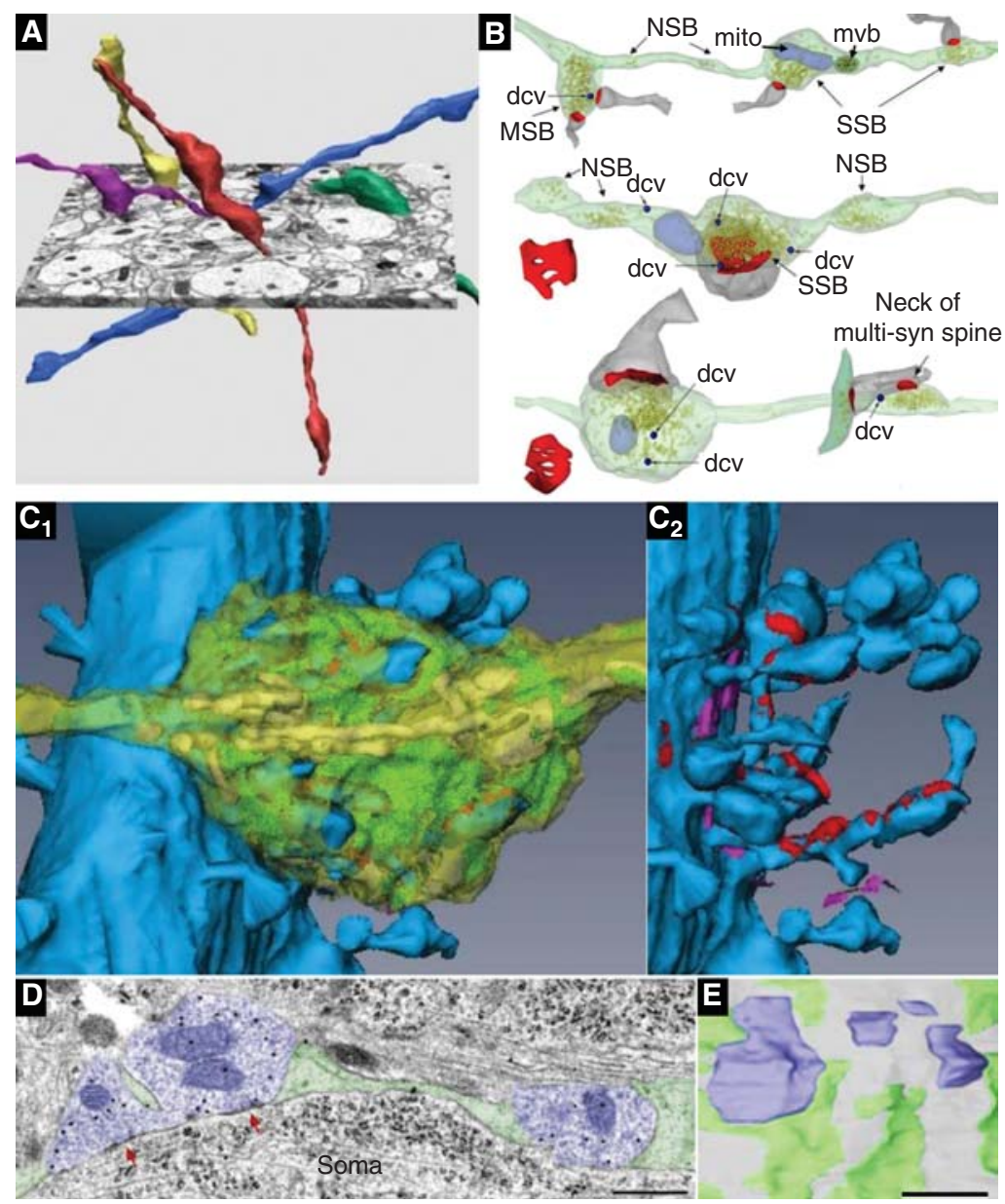

Figure 3. Presynaptic axons. (A) Three-dimensional (3D) reconstructions of CA3-to-CA1 axons (Schaffer collaterals). (B) 3D reconstructions of axons with vesicles (yellow) and associated postsynaptic partners (dendritic spine, gray; PSD surface, red). Typical single synaptic boutons (SSB) have a single postsynaptic partner, multisynaptic boutons (MSB) have more than one postsynaptic partner, and nonsynaptic boutons (NSB) contain vesicles but have no postsynaptic partners. Also illustrated are small dense core vesicles (dcvs, dark blue), mitochondria (mito, pale blue), and a multivesicular body (mvb, dark green with brown vesicles). $\left(C_{1}\right)$ 3D reconstruction of a proximal CA3 pyramidal cell dendrite (blue) and a large mossy fiber bouton (translucent yellow), which contains numerous mitochondria (yellow) and vesicles (green). The cut-away in $C_{2}$ shows synapses (red) onto multiple dendritic spines, some of which are highly branched. The bouton also forms nonsynaptic cell adhesion junctions (fuchsia). (D) Electron micrograph through inhibitory presynaptic boutons (purple) that form symmetric synapses (red arrows) on the soma of a CA1 pyramidal cell. Scale bar, $500 \mathrm{~nm}$. (E) 3D reconstruction of four complete inhibitory synaptic boutons ( purple) interspersed with glial processes (green) on the surface of a CA1 pyramidal cell soma (gray). The magnifications of all 3D images in $A-C$ have been rescaled to match the 1- $\mu \mathrm{m}$ scale bar in $E$. (Panel $A$ is from Shepherd and Harris 1998; reprinted, with permission, from the authors; $B$ is from Sorra et al. 2006; reprinted, with permission, from the authors; the image in panel $C$ is modified from a supplemental movie by Rollenhagen et al. 2007; reprinted, with permission, from the Journal of Neuroscience (C) 2007; panels $D$ and $E$ are from Ledoux and Woolley 2005; reprinted, with permission, from the Journal of Neuroscience (C) 2005.) 
K.M. Harris and R.J. Weinberg
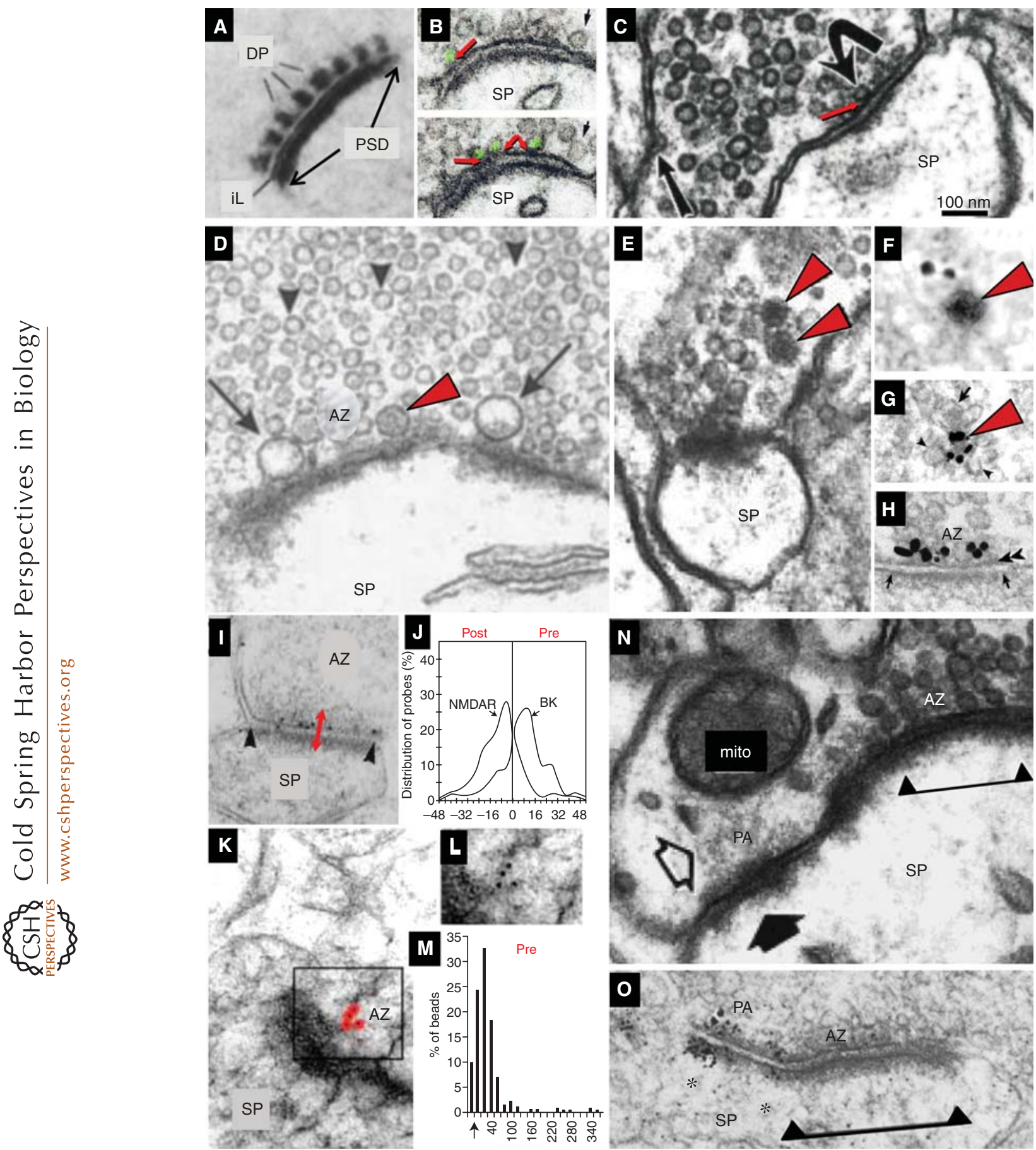

Figure 4. Presynaptic active zone (AZ) and vesicles. (A) Presynaptic dense projections (dp), a postsynaptic density (PSD), and the "intercleft line" (iL) at cerebellar synapses, revealed by ethanolic phosphotungstic acid. (B) Two serial sections through a parallel fiber synapse on a dendritic spine (Sp) in cerebellar cortex illustrate docked synaptic vesicles (green), which have no cytoplasm between the membrane of the vesicle and the AZ membrane (red arrows). (See facing page for legend.) 
photoreceptors, hair cells), the dense projections form a specialized "synaptic ribbon" also thought to dock and prime vesicles for release (LoGiudice and Matthews 2009). Recent work with cryoelectron tomography in tissue culture and organotypic slices suggests that the complex network of filaments in the AZ changes dimensions during release, further supporting its role in vesicle mobilization and release (Fernandez-Busnadiego et al. 2010).

\section{Vesicles in Axonal Boutons}

Presynaptic boutons of excitatory synapses contain round, clear vesicles $(\sim 35 \mathrm{~nm}$ diameter) loaded with the neurotransmitter glutamate (Harris and Sultan 1995; Qu et al. 2009). Vesicles distributed throughout the presynaptic bouton compose a "reserve" pool distinct from the anatomically docked vesicles that contact the presynaptic membrane at the AZ (Fig. 4B,C). Neurotransmitter is released from a docked vesicle into the synaptic cleft. Vesicles docked at the presynaptic active zone are often smaller than nondocked vesicles, as if some of their contents had been released at the time of fixation (Harris and Sultan 1995). After release, the vesicular membrane is recycled via clathrin-mediated endocytosis (Fig. 4C) or via bulk endocytosis, especially with strong stimulation (Clayton and Cousin 2009; Royle and Lagnado 2010).

Presynaptic boutons can also contain other vesicles of diverse shapes, sizes, and content (Torrealba and Carrasco 2004). In addition to the typical small synaptic vesicles, some excitatory glutamatergic synapses also contain larger clear vesicles (>60 nm), consistent with the occurrence of "giant" miniature EPSCs at these synapses (Fig. 4D) (Henze et al. 2002). In addition to the clear vesicles, some glutamatergic axonal varicosities contain dense core vesicles ( $~ 80 \mathrm{~nm}, \mathrm{DCV})$ among the pool of clear vesicles (Fig. 4E). A few (1-10) DCVs are present in $\sim 20 \%$ of mature presynaptic boutons in CA1 (Sorra et al. 2006). The outer membranes of these DCVs label with antibodies to proteins like Piccolo and Bassoon (Fig. $4 \mathrm{H}$ ), which also concentrate at the AZ (Fig. 4H). Similar immunolabeled vesicles are common along axons in the developing nervous system, suggesting that

Figure 4. (Continued) The small black arrow points to a vesicle close to the membrane, but not docked. $(C)$ Hippocampal CA3 $\rightarrow$ CA1 synapse; note the docked vesicle (curved arrow, red arrow) and a presynaptic endocytic zone identified by a coated pit (straight arrow). (D) Large clear vesicles (arrows) and a DCV (red arrowhead) at the presynaptic AZ, and nondocked small synaptic vesicles in the reserve pool (arrowheads) of a CA3 mossy fiber bouton synapsing with a large dendritic spine (SP). (E) Small DCVs (red arrowheads) colocalize with small clear vesicles at a hippocampal CA1 spine synapse; and pre-embedding immunogold labeled for Piccolo $(F)$ and Bassoon $(G)$. (H) Bassoon localized to the AZ. (I) Post-embedding immunogold labeling for the big potassium channel (BK) located at the presynaptic active zone of a synapse on a small dendritic spine in s. radiatum of area CA1 (double-headed red arrow). $(J)$ Positions of gold particles were compiled from the postsynaptic to presynaptic side; the glutamatergic NMDA receptor concentrated on the postsynaptic side, whereas BK channels concentrated on the presynaptic side (gold particles for NMDA are not visible in $I$ ). $(K)$ Postembedding immunogold labeling for CAST. Gold particles have been colored red for emphasis; original version of boxed region is shown in $L$. (M) Quantitative distribution of CAST with distance (in nanometers) from the presynaptic plasma membrane (arrow on $x$-axis). $(N)$ Puncta adherens (PA) adjacent to the synaptic active zone (delimited beneath the PSD by triangles and line) of a large CA1 dendritic spine. (O) Silver-enhanced immunogold labeling for the cell adhesion molecule $\beta$-catenin, at the edge of an AZ on a cerebellar dendritic spines. All images have been scaled to match the 100-nm bar in C. (Panel $A$ is adapted from van der Want et al. 1984; reprinted, with permission, from Elsevier (C) 1984; panel $B$ is from Xu-Friedman et al. 2001; reprinted, with permission, from the author; panel $C$ is from Harris and Sultan 1995; reprinted, with permission, from the author; panel $D$ is from Henze et al. 2002; reprinted, with permission, from the author; panel $E$ is from Sorra et al. 2006; reprinted, with permission, from the author; panel $F$ is from Zhai et al. 2001, panels $G$ and $H$ are from TaoCheng 2007; reprinted, with permission, from Elsevier (C) 2001; panels $I$ and $J$ are from Hu et al. 2001; reprinted, with permission, from the Journal of Neuroscience (C) 2001; panels $K-M$ are modified from Siksou et al. 2007; panel $N$ is from Spacek and Harris 1998; reprinted, with permission, from the author; panel $O$ is modified from Uchida et al. 1996.) 
these DCVs are a local source of new AZs (Ahmari and Smith 2002; Ziv and Garner 2004). In support of this hypothesis, DCVs are lost from presynaptic axonal boutons during rapid synaptogenesis in the mature hippocampus, as would be expected if they had been used to generate new AZ sites (Sorra et al. 2006).

Inhibitory presynaptic boutons contain slightly smaller vesicles of both round and flattened shapes in aldehyde-fixed tissue (Fig. 2E,F). Rapid freezing reveals rounder vesicles in the symmetric synapses (Tatsuoka and Reese 1989), suggesting that differences in the subvesicular composition of excitatory and inhibitory synaptic vesicles may render those at symmetric synapses more susceptible to shape changes during aldehyde fixation. The vesicles at symmetric synapses usually contain the neurotransmitters GABA or glycine. Inhibitory synapses are most abundant at the neuronal soma and along proximal dendritic shafts. Inhibitory synapses are also interspersed among the excitatory synapses along dendrites; for example, $\sim 5 \%-$ $10 \%$ of the synapses along a dendrite in stratum radiatum of area CA1 are inhibitory. Inhibitory synapses are sometimes found at the axon hillock, where their activation might provide especially potent inhibition. In some brain regions, inhibitory synapses can also be found on the necks of dendritic spines (Wilson et al. 1983; Dehay et al. 1991; Knott et al. 2002). Some neuropeptides, as well as aminergic neurotransmitters, are typically packaged in large $(\sim 100 \mathrm{~nm})$ dense core vesicles (Bauerfeind et al. 1995; Torrealba and Carrasco 2004; Crivellato et al. 2005), although neuropeptides have also been detected in the cytoplasm surrounding pleiomorphic vesicles of inhibitory synapses (Harris et al. 1985).

\section{Other Axonal Components}

Microtubules are cytoskeletal elements that interact with dynein- and kinesin-based motors to transport vesicles, mitochondria, smooth endoplasmic reticulum, and endosomal compartments along axons. Microtubules are obvious along axons (e.g., see http://synapses.clm.utexas. edu/atlas/1_1_8intro.stm) but are uncommon within central synaptic boutons, perhaps because the calcium transients associated with transmitter release cause their depolymerization under normal conditions (Weisenberg 1972; Gray 1975; Weisenberg and Deery 1981; Gray et al. 1982; O’Brien et al. 1997). Similar activity-dependent effects may explain their absence in dendritic spines (see below), in contrast to the transient formation of microtubules in spines during early development and when synapses are completely inactive (Westrum et al. 1980; Fiala et al. 2003).

Mitochondria are distributed heterogeneously along axons and in presynaptic boutons. In hippocampal CA1, for example, only $41 \%$ of presynaptic boutons contain mitochondria (e.g., Fig. 3B) (Shepherd and Harris 1998). In contrast, some large boutons each contain many mitochondria (e.g., Fig. 3C). Sorting endosomes are associated with multivesicular bodies (see Fig. $3 \mathrm{~B}$, top axon) that transport dysfunctional proteins and membrane from presynaptic boutons back to the soma for degradation. Recent work in cultured hippocampal axons shows that local protein synthesis is needed for vesicular release (Sebeo et al. 2009), but polyribosomes are uncommon in presynaptic boutons in the CNS. In squid giant axons, the local protein synthesis machinery appears to derive from the ensheathing glia (Crispino et al. 1997; Eyman et al. 2007); whether perisynaptic astroglial processes are a source of local synthesis at mammalian synapses remains an open question (Chicurel et al. 1993).

\section{Molecular Anatomy of the Active Zone}

Extensive research has focused on the biochemistry of presynaptic vesicles and transmitter release (Sudhof 1995, 2004; Schoch and Gundelfinger 2006; Takamori et al. 2006; Rizzoli and Jahn 2007). Notwithstanding recent dramatic advances in super-resolution light microscopy (Willig et al. 2006; Balaji and Ryan 2007; Dani et al. 2010), immuno-EM remains the standard method to investigate the nanoscale distribution of proteins within the presynaptic bouton. The most common technique uses peroxidase-based enzymatic amplification 
to generate an electron-dense diaminobenzidine reaction product. However, diffusion of the product typically leads to a localization uncertainty of $\sim 100 \mathrm{~nm}$. In this article, we focus on anatomical results based on immunogold methods, which provide a more quantitative and spatially accurate signal.

The cytomatrix proteins Bassoon and Piccolo concentrate at the AZ (Fig. 4H) (Zhai et al. 2001; Siksou et al. 2007; Tao-Cheng 2007). Voltage-, ligand-, and calcium-gated channels and transporters have also been detected in the AZ by immunogold labeling (e.g., the BK channel) (Fig. 4I,J), consistent with their functions in synaptic transmission (He et al. 2000; Miner et al. 2000, 2003; Hu et al. 2001; Tamaru et al. 2001; Darstein et al. 2003; Kulik et al. 2004; Nyiri et al. 2005; Serwanski et al. 2006; Tremblay et al. 2007; Furness et al. 2008; Ladera et al. 2008; Melone et al. 2009; Needleman et al. 2010). Several studies have provided immunogold evidence for other proteins at the active zone that may play a direct role in transmitter release, including CAST (Fig. 4K-M) and RIM1 (Hagiwara et al. 2005; Tao-Cheng 2006). Surprisingly, the tSNARE-related proteins syntaxin and SNAP-25 show no obvious enrichment at the AZ (Hagiwara et al. 2005). Most of the membrane-bound proteins found in the $\mathrm{AZ}$ can also be detected away from it. In fact, a few receptors (e.g., mGluR3) (Tamaru et al. 2001) and most of the neurotransmitter transporters (He et al. 2000; Miner et al. 2000, 2003; Chen et al. 2002; Melone et al. 2009) are found at the presynaptic membrane close to the synaptic region but may be selectively excluded from the AZ itself.

Beyond the region of the active zone, immunogold data on proteins within presynaptic boutons from mammalian forebrain are quite limited, although one may extrapolate from more tractable models like the giant synapse of the lamprey (Bloom et al. 2003; Brodin and Shupliakov 2006). PICK1, synuclein, and CaM$\mathrm{KII} \alpha$ have been reported within the presynaptic cytoplasm of hippocampal neurons (TaoCheng et al. 2006; Tao-Cheng 2007; Haglerod et al. 2009). Different types of filaments appear to link presynaptic vesicles (Siksou et al. 2007, 2009). The chemical identity of these filaments remains uncertain, although both synapsin and actin are probably involved (Hirokawa 1989; Doussau and Augustine 2000).

\section{THE SYNAPTIC CLEFT}

The synaptic cleft is a widening $(\sim 20 \mathrm{~nm})$ in the apposition between the presynaptic axon and its postsynaptic partner. Consistent with classical reports, recent ultrastructural work on quick-frozen hydrated material emphasizes that this widening is not really a "space," but is instead packed with electron-dense material (Lucic et al. 2005; Zuber et al. 2005). The cleft appears to contain both standard extracellular matrix proteins and specialized synaptic proteins (Dityatev et al. 2010), but little direct immunogold evidence is available, except for the secreted pentraxins Narp and NP1 (O'Brien et al. 1999; Xu et al. 2003).

The synapse is a highly specialized adhesive junction. It is thus not surprising that several classes of adhesion molecules have also been identified at the synapse, including proteins of the immunoglobulin superfamily, integrins, neuroligin/neurexins, and ephrin/eph receptors (Gerrow and El-Husseini 2006; Craig and Kang 2007; Dalva et al. 2007; Shapiro et al. 2007; Dityatev et al. 2008; Togashi et al. 2009; Woo et al. 2009; Zipursky and Sanes 2010). Beyond their role in structural organization and maintenance of the synapse, many of these adhesion molecules play a special role in synaptogenesis and/or in long-term synaptic plasticity. Immunogold labeling has detected many adhesion molecules at or near synaptic membranes; however, even immunogold methods cannot readily resolve whether the labeling is strictly presynaptic, strictly postsynaptic, or both. Proteins for which immunogold data are available include NCAM (Fux et al. 2003), nectin (which associates with the actin-binding protein afadin and the synaptic scaffold molecule S-SCAM) (Nishioka et al. 2000; Mizoguchi et al. 2002; Yamada et al. 2003), cadherins and protocadherins (Fannon and Colman 1996; Phillips et al. 2003; Petralia et al. 2005; Huntley et al. 2010; Li et al. 2010), $\alpha$ - and $\beta$-catenin (Uchida et al. 1996; Petralia et al. 2005, 2010), neuroligin/ 
K.M. Harris and R.J. Weinberg

neurexin family members (Song et al. 1999; Petralia et al. 2005; Taniguchi et al. 2007; Kasugai et al. 2010), ephrins/Eph receptors (Buchert et al. 1999; Tremblay et al. 2007), NGL (Kim et al. 2006), SALM (Seabold et al. 2008), and CASK, which can bind to syndecan, a heparan sulfate proteoglycan on the cell surface (Hsueh et al. 1998). Some of these proteins concentrate just outside the synaptic specialization, consistent with ultrastructural observations of puncta adherens seen at the edges of synapses (Fig. 4N) (Spacek and Harris 1998; Latefi and Colman 2007); thus, for example, immunogold labeling for $\alpha \mathrm{N}$ - and $\beta$-catenin concentrates at puncta adherens near the edges of synapses (Fig. 4O).

\section{POSTSYNAPTIC DENDRITIC SPINES}

Dendritic spines vary greatly in their dimensions, not only across brain regions (Table 1), but even along short segments of a single dendrite. For example, spines along Purkinje cell dendrites (which synapse in the molecular layer with parallel fibers) all have similar "lollipop" shapes, with a bulbous head on a constricted neck (Fig. 5A). In contrast, dendritic spines in
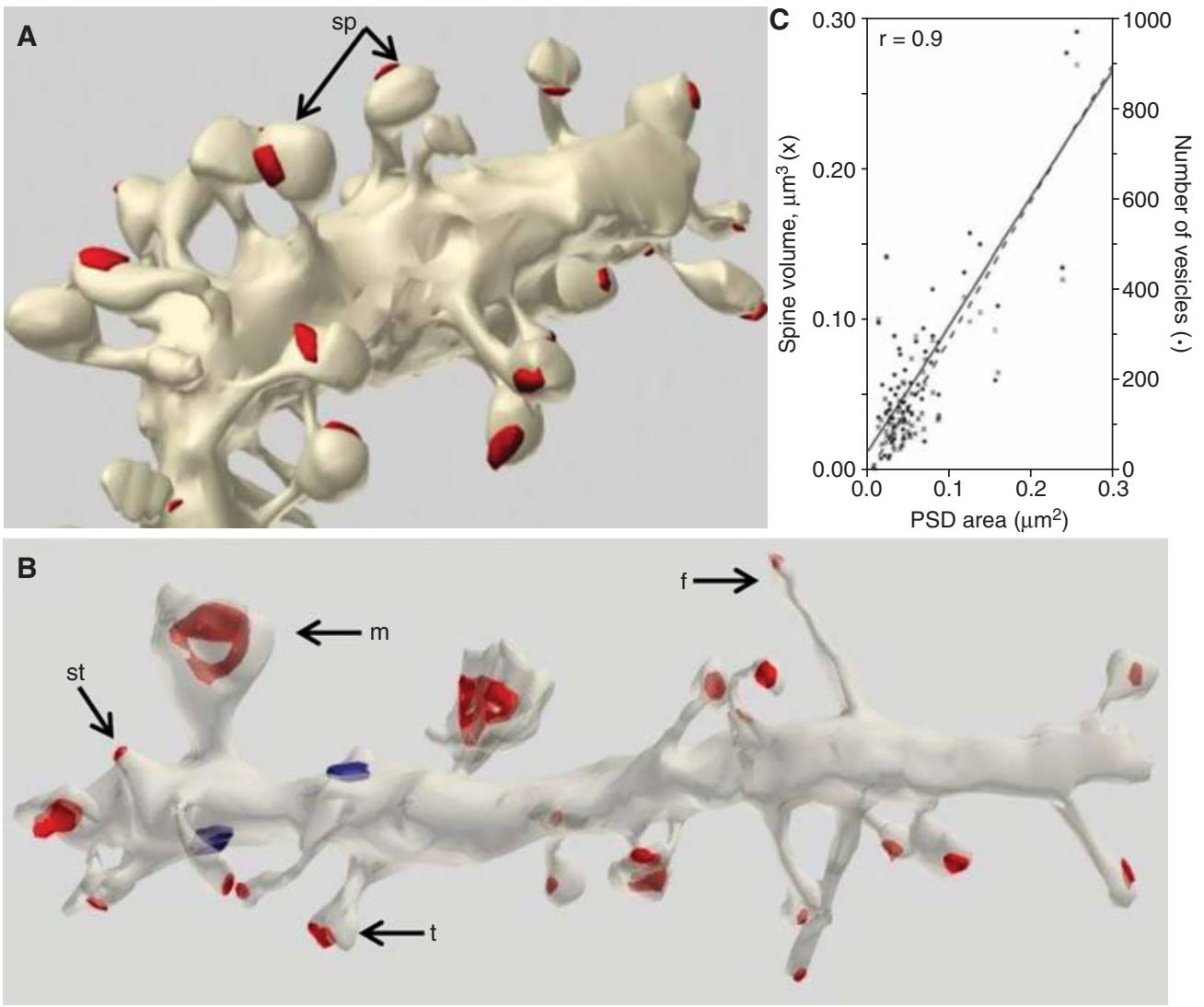

Figure 5. Postsynaptic dendritic spines. (A) 3D reconstruction of cerebellar Purkinje cell dendrite; note the relatively uniform shape of the dendritic spines (arrows). (B) 3D reconstruction of hippocampal CA1 dendrite, showing immature filopodia-like ( $\mathrm{f}$ ) and stubby (st) protrusions on the same segment as spines with mushroom $(\mathrm{m})$ and thin $(\mathrm{t})$ shapes. Scale, $1 \mu \mathrm{m}$; the red surfaces are the PSD areas for both $A$ and $B$. (C) The area of the PSD at hippocampal synapses is strongly correlated with both the volume of the spine (left $y$-axis) and the number of vesicles in the presynaptic boutons (right $y$-axis). (Panels $A$ and $B$ are from http://synapses.clm.utexas.edu/ anatomy/compare/compare.stm; reprinted, with permission, from J. Spacek; panel $C$ is from Lisman and Harris 1993; reprinted, with permission, from the author.) 
hippocampus are much more variable in shape; even neighboring protrusions can vary from immature "filopodia-like" to mature mushroomshaped spines (Fig. 5B) (Bourne and Harris 2010). In both regions, the size of the spine head correlates remarkably well with the number of presynaptic vesicles (Fig. 5C).

Table 1 summarizes spine dimensions and densities based on 3D reconstructions of dendritic segments from serial-section EM. The average dendritic spine on a cerebellar Purkinje cell is about twice as big $\left(0.12 \mu \mathrm{m}^{3}\right)$ as the average spine on a hippocampal pyramidal cell in the s. radiatum of CA1 $\left(0.054 \mu \mathrm{m}^{3}\right)$, but not in s. lacunosum-moleculare $\left(0.11 \mu \mathrm{m}^{3}\right)$. However, the range in spine volumes is much greater in area CA1 $\left(0.003-0.56 \mu \mathrm{m}^{3}\right)$ than in cerebellum $\left(0.06-0.18 \mu \mathrm{m}^{3}\right)$. The distributions are not normal but highly skewed, and additional quantitative data would provide further insight. For example, the CA1 hippocampus (the brain region with the largest available body of quantitative data) contains numerous small spines and a few very large spines that contain dendritic core structures such as polyribosomes and are associated with enlarged synapses following long-term potentiation (e.g., Bourne and Harris 2010). Whether the difference in range of dendritic spine sizes between cerebellum and hippocampus reflects an underlying difference in capacity for structural plasticity remains an open question.

\section{Ultrastructure of the Postsynaptic Density}

The most prominent postsynaptic component of excitatory synapses is the postsynaptic density (PSD), identified as a fuzzy electron-dense structure extending $\sim 35-50 \mathrm{~nm}$ into the cytoplasm beneath the plasma membrane at asymmetric synapses (Gulley and Reese 1981; Landis and Reese 1983). The reconstructed surface of small synapses is usually regular (although not truly circular) and becomes more complex with size; many of the largest synapses are "perforated" by interior holes devoid of PSD material (Figs. 2, 5). The electron-dense fuzz that defines the PSD is apposed to the postsynaptic membrane in tight registry with the presynaptic ac- tive zone, likely reflecting direct trans-synaptic interactions. The degree of presynaptic and postsynaptic thickening varies greatly even among excitatory or inhibitory synapses in the same brain region (Colonnier 1968) (see also http://synapses.clm.utexas.edu/anatomy/ chemical/colh.htm). PSD thickness is also sensitive to experimental manipulations (e.g., hypoxia or intense stimulation) that impact the subcellular organization of constituent proteins (Hu et al. 1998; Otmakhov et al. 2004; TaoCheng et al. 2007). The surface area of the PSD correlates nearly perfectly with spine head volume and the total number of presynaptic vesicles (Fig. 5C), and with the number of vesicles docked at the AZ (Harris and Stevens 1988b; Lisman and Harris 1993; Harris and Sultan 1995; Schikorski and Stevens 2001).

\section{Molecular Anatomy of the PSD}

The PSD contains a variety of receptors, scaffolding proteins, and signaling complexes involved in synaptic transmission and plasticity (see Sheng and Kim 2011). The biochemically isolated PSD has a molecular weight of $\sim 1$ billion daltons (Chen et al. 2005), and proteomic studies have identified hundreds of proteins in the PSD fractions. Antibodies have been raised to many of these proteins, but the dense matrix of the PSD limits antibody access, and extensive noncovalent protein-protein linkages interfere with antibody binding (Fukaya and Watanabe 2000; Burette et al. 2001). Thus, the standard "pre-embedding" technique, which relies on silver enhancement of tiny $(\sim 1 \mathrm{~nm})$ gold particles conjugated to a secondary antibody, may give a misleading impression that antigen is sparse or absent from the PSD, although the technique is effective for detecting nonsynaptic protein. Several strategies have been developed to address the problem. We first focus on proteins that have been found in the PSD with immunogold labeling via post-embedding methods, in which the immune reaction is performed directly on the EM grid. By exposing antibody only to the surface of the thin section, this method provides equal access to all tissue compartments exposed by the knife, allowing an unbiased 


\section{$\&_{\mathrm{CSH}}^{\infty}$ Cold Spring Harbor Perspectives in Biology

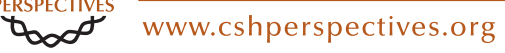

Table 1. Dendritic spine and synapse dimensions

\begin{tabular}{|c|c|c|c|c|c|c|}
\hline $\begin{array}{l}\text { Brain region } \\
\text { (cell/spine type) }\end{array}$ & $\begin{array}{l}\text { Spine density } \\
(\# / \mu \mathrm{m} \text { dendrite })\end{array}$ & $\begin{array}{l}\text { Spine volume } \\
\left(\mu \mathrm{m}^{3} \text { or } \mathrm{fl}\right)\end{array}$ & $\begin{array}{l}\text { Spine surface } \\
\text { area }\left(\mu \mathrm{m}^{2}\right)\end{array}$ & $\begin{array}{l}\text { PSD area } \\
\left(\mu \mathrm{m}^{2}\right)\end{array}$ & $\begin{array}{l}\text { Neck diameter } \\
(\mu \mathrm{m})\end{array}$ & References \\
\hline \multicolumn{7}{|l|}{ Adult rats } \\
\hline CA1, SR & $2.89^{\#}$ & $\begin{array}{l}0.054^{\#} \\
\quad(0.003-0.56)\end{array}$ & $\begin{array}{c}0.83 \pm 0.63^{* *} \\
\quad(0.13-4.4)\end{array}$ & $\begin{array}{l}0.069^{\#} \\
\quad(0.008-0.54)\end{array}$ & $\begin{array}{l}0.14^{\#} \\
\quad(0.027-0.99)\end{array}$ & $\begin{array}{l}\text { Harris and Stevens (1988); Megias et al. } \\
\text { (2001); Cooney et al. (2002); Bourne } \\
\text { et al. (2007b); Popov et al. (2007); } \\
\text { Nicholson and Geinisman (2009); } \\
\text { Mishchenko et al. (2010) }\end{array}$ \\
\hline CA1, SL-M & $0.81^{\#}$ & $\begin{array}{l}0.11^{* \mathrm{a}} \\
\quad(0.006-0.52)\end{array}$ & & $\begin{array}{l}0.090^{* \mathrm{a}} \\
\quad(0.018-0.42)\end{array}$ & $\begin{array}{l}0.166^{* a} \\
(0.043-0.72)\end{array}$ & $\begin{array}{l}\text { Megias et al. (2001); Donohue et al (2006); } \\
\text { Nicholson and Geinisman (2009) }\end{array}$ \\
\hline $\begin{array}{l}\text { CA3 (thorny } \\
\text { excrescences) }\end{array}$ & & $1.17 \pm 0.15^{* * *}$ & $15.1^{\#}(9.2-35.9)$ & $\begin{array}{r}2.4 \pm 1.3^{* * \mathrm{~b}} \\
(0.91-5.1)\end{array}$ & & $\begin{array}{l}\text { Chicurel and Harris (1992); Rollenhagen } \\
\text { et al. (2007); Stewart et al. (2005) }\end{array}$ \\
\hline $\begin{array}{l}\text { Cerebellum } \\
\quad \text { (Purkinje cells) }\end{array}$ & $4.87^{* \mathrm{c}}(2.0-14.3)^{\mathrm{f}}$ & $\begin{array}{r}0.12 \pm 0.02^{* *} \\
\quad(0.06-0.18)\end{array}$ & $\begin{array}{r}1.12 \pm 0.18^{* *} \\
(0.69-1.63)\end{array}$ & $\begin{array}{r}0.15 \pm 0.08^{* *} \\
\quad(0.04-0.36)\end{array}$ & $\begin{array}{r}0.20 \pm 0.04^{* *} \\
(0.09-0.31)\end{array}$ & Harris and Stevens (1988); Lu et al. (2009) \\
\hline $\begin{array}{l}\text { Striatum (medium } \\
\text { spiny neurons) }\end{array}$ & $(2.2-4.6)$ & $0.12^{*}(0.04-0.33)$ & $1.46^{*}(0.61-3.14)$ & & $(0.1-0.5)$ & Wilson et al. (1983) \\
\hline Lateral amygdala & $2.1^{* \mathrm{~d}}$ & & $\begin{array}{l}0.7^{*}\left(\mathrm{SA}^{-}\right)^{\mathrm{e}} \\
\quad 2.2^{*}\left(\mathrm{SA}^{+}\right)^{\mathrm{e}}\end{array}$ & $\begin{array}{l}0.05^{*}\left(\mathrm{SA}^{-}\right)^{\mathrm{e}} \\
\quad 0.19^{*}\left(\mathrm{SA}^{+}\right)^{\mathrm{e}}\end{array}$ & & Ostroff et al. (2010) \\
\hline \multicolumn{7}{|l|}{ Adult mice } \\
\hline CA1 & & $0.038 \pm 0.036^{* *}$ & & $0.043 \pm 0.031^{* *}$ & & Schikorski and Stevens (1997) \\
\hline Cerebellum & & $\begin{array}{r}0.18 \pm 0.06^{* *} \\
(0.06-0.42)\end{array}$ & $\begin{array}{r}1.86 \pm 0.36^{* *} \\
\quad(1.08-3.10)\end{array}$ & $\begin{array}{r}0.13 \pm 0.06^{* *} \\
(0.03-0.27)\end{array}$ & & Spacek and Hartmann (1983) \\
\hline Visual cortex & & $0.15^{\#}(0.01-0.81)$ & $\begin{array}{r}2.08 \pm 0.83^{* *} \\
(0.48-4.76)\end{array}$ & $\begin{array}{l}0.15^{\#} \\
\quad(0.01-0.69)\end{array}$ & $\begin{array}{r}0.20 \pm 0.06^{* *} \\
(0.09-0.51)\end{array}$ & $\begin{array}{l}\text { Spacek and Hartmann (1983); Arellano } \\
\text { et al. (2007) }\end{array}$ \\
\hline Barrel cortex & $0.45^{*}-0.83^{*}$ & $(0.015-0.77)$ & $(0.36-4.24)$ & $(0.006-0.64)$ & & Knott et al. (2006) \\
\hline Piriform cortex & & $0.10^{\#}$ & & $0.098^{\#}$ & & Schikorski and Stevens (1999) \\
\hline
\end{tabular}

\# Median of the means reported in cited studies.

* Mean.

** Mean \pm SD.

*** Mean \pm SEM (range).

${ }^{a}$ Mean was calculated across all spine types from the means and sample sizes reported in Nicholson and Geinisman (2009; Table 3).

${ }^{\mathrm{b}}$ Mean \pm SD was calculated from data reported in Rollenhagen et al. (2007; Table 1) to include all thorny excrescences from two age groups (P28 and P90-120).

${ }^{\mathrm{c}}$ Mean was calculated from data reported in Lu et al. (2009) to include all Purkinje cell dendritic segments receiving granule cell inputs.

${ }^{\mathrm{d}}$ Mean was calculated from data reported in Ostroff et al. (2010, Fig. 2G) to combine all types of spines.

${ }^{\mathrm{e}} \mathrm{SA}^{-}$, spines not containing spine apparatus; $\mathrm{SA}^{+}$, spines containing spine apparatus.

${ }^{\mathrm{f}}$ Values in parentheses indicate range. 
estimate of antigen distribution. Alternatively, the immunogold reaction can be performed directly on biochemically isolated PSDs ("immunogold-PSD"); the disruption associated with biochemical purification exposes antigen to the reagents and allows high sensitivity and specificity, although exposure is limited to the exterior surfaces. A recently developed method provides similar advantages by performing the immunoreaction on a specially prepared freeze-fractured replica ("SDS-FRL") as discussed below.

Proteins in the PSD show a laminar distribution in the orthogonal ("axo-dendritic") axis when immunolabeled on ultrathin sections (Fig. 6A-C) (Valtschanoff and Weinberg 2001; Petersen et al. 2003), as confirmed by superresolution light microscopy (Dani et al. 2010). The exterior face of the PSD is rich in neurotransmitter receptors and trans-synaptic adhesion molecules embedded within the plasma membrane. Beneath the receptors resides a dense matrix of proteins, including scaffold, actinbinding, and downstream signaling molecules. Ionotropic glutamate receptors concentrate in the plasma membrane at the PSD (for review, see Ottersen and Landsend 1997; Nusser 2000; Darstein et al. 2003; Masugi-Tokita and Shigemoto 2007). AMPAR labeling is directly proportional to PSD area, whereas the relationship between NMDAR labeling and PSD area is much weaker, implying that the smallest synapses may lack AMPARs completely (Nusser et al. 1998; Kharazia and Weinberg 1999; Takumi et al. 1999; Racca et al. 2000). The axospinous synapses on Purkinje cells appear to lack NMDARs but express high levels of the orphan receptors $\delta 1$ and $\delta 2$ (Zhao et al. 1998). Functional AMPARs are tightly linked to accessory proteins including the Stargazin family of transmembrane AMPA regulatory proteins (TARPs) (Fukaya et al. 2006). A few other membranebound receptors concentrate within the PSD (e.g., TrkB) (Petralia et al. 2005). Interestingly, NMDA receptors may be localized more centrally than AMPARs, whereas group I metabotropic glutamate receptors concentrate in an annulus just outside the edge of the PSD (Luján et al. 1996; Kharazia and Weinberg 1997; Kennedy 2000; Racca et al. 2000). Post-embedding immunogold has also detected $\mathrm{P} 2 \mathrm{X}$ receptors at the PSD (Rubio and Soto 2001).

The best known group of scaffold proteins lying within the postsynaptic density is the PSD-95 family of MAGUK proteins, including PSD-95, PSD-93, SAP102, and SAP97 (Kim and Sheng 2004; Feng and Zhang 2009). MAGUKs contain several PDZ domains, an SH3 domain, and an (enzymatically dead) guanylate kinase domain; each domain has characteristic binding partners. The scaffold proteins concentrate in a zone $10-20 \mathrm{~nm}$ inside the plasma membrane (Fig. 6A,B) (Sans et al. 2000; Valtschanoff et al. 2000; Valtschanoff and Weinberg 2001) and are fairly uniformly distributed tangentially along the synaptic membrane, except for SAP97, which concentrates at the edge of the synapse and is thought to interact selectively with the AMPAR subunit GluA1. Recent results using the immunogold-PSD technique confirm these conclusions within the isolated PSD (DeGiorgis et al. 2006; Swulius et al. 2010). PSD-95 was originally thought to play a special role in anchoring NMDARs, but more recent evidence suggests that PSD-95 may be at least as important in regulating the surface expression of AMPARs (Schnell et al. 2002; Ehrlich and Malinow 2004).

Two other multi-PDZ proteins, GRIP (also known as GRIP1) and ABP (or GRIP2), concentrate at the PSD (Srivastava et al. 1998; Wyszynski et al. 1999). Both were originally thought to anchor AMPARs at the PSD, but current evidence points to a role in AMPAR trafficking, as suggested also by the considerable cytoplasmic immunogold labeling. The single PDZ-domain protein PICK1, also implicated in AMPAR trafficking, is located mainly in the cytoplasmic portion of the PSD (Haglerod et al. 2009). The GKAP/SAPAP proteins, which can bind to MAGUK family scaffolds, also lie in this intermediate zone of the PSD (Fig. 6A-C) (Naisbitt et al. 1997; Petralia et al. 2005), as do CRIPT and IRSp53, two other MAGUK interacting proteins (Niethammer et al. 1998; Choi et al. 2005). Coupling to the SAPAP proteins is the Shank family of scaffold proteins, which lies on the cytoplasmic margin of the PSD (Naisbitt et al. 1999; Petralia et al. 2005). Shank proteins, in turn, can bind to the Homer family (associated 
K.M. Harris and R.J. Weinberg
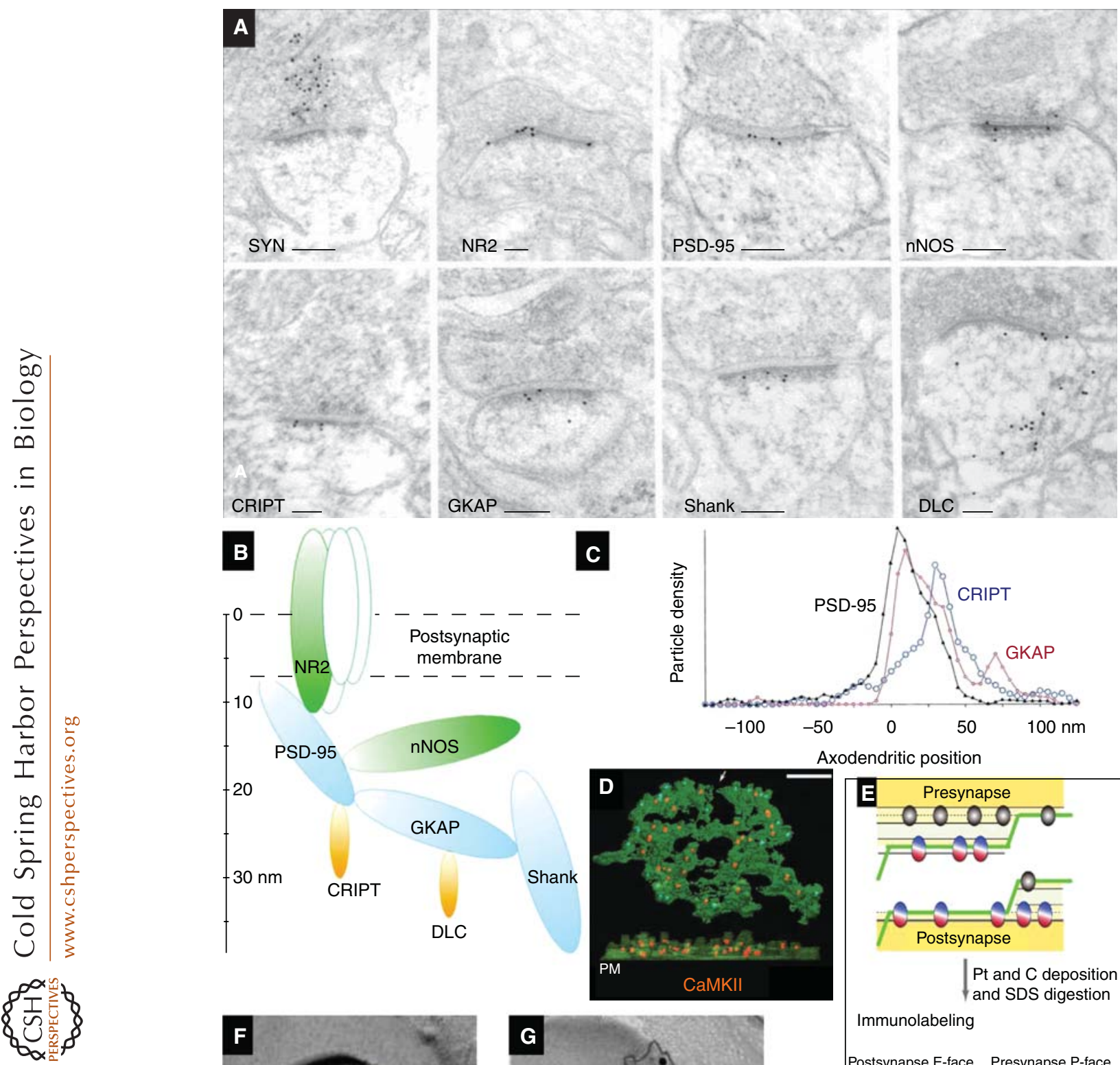

c
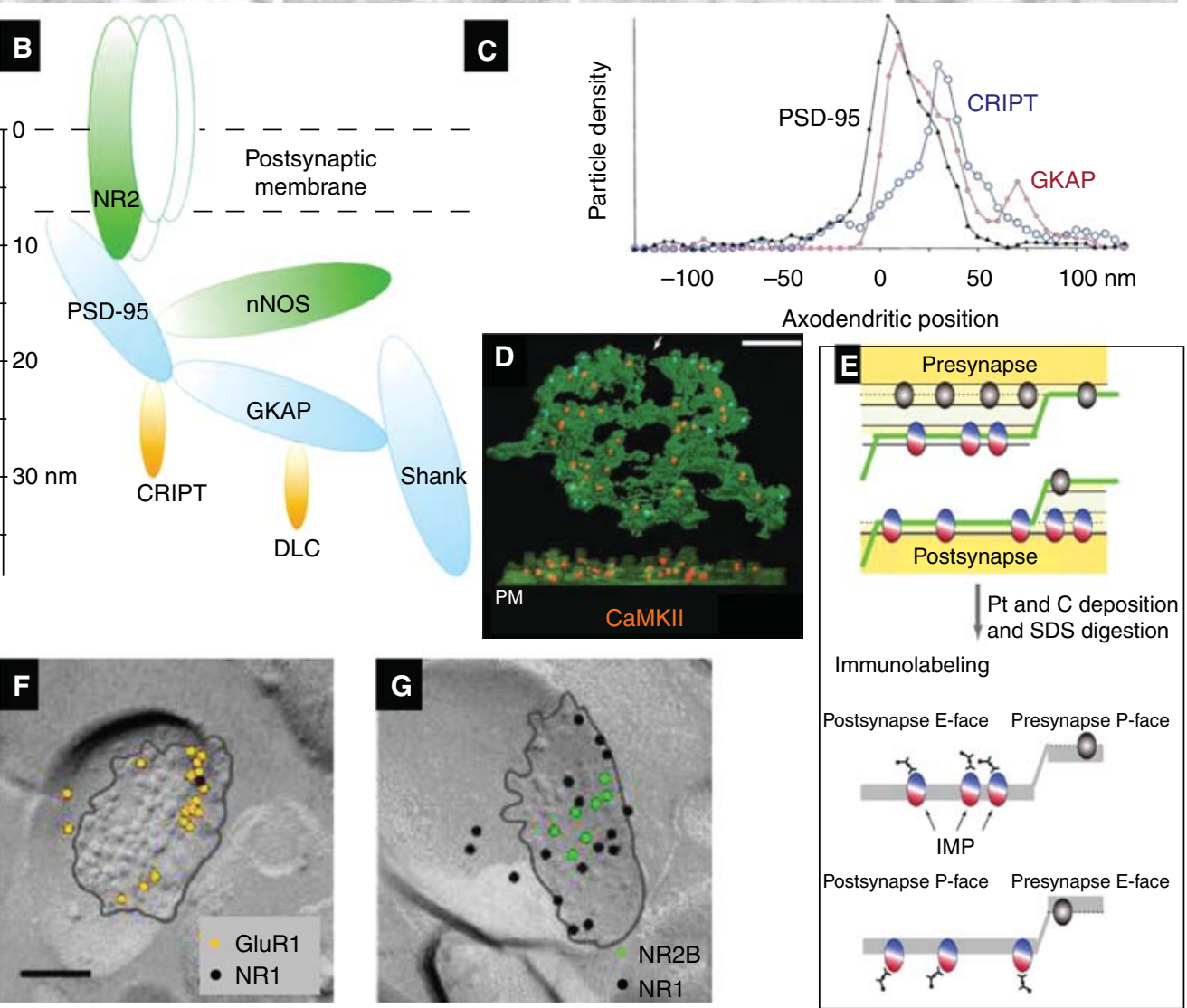

Figure 6. Molecular anatomy of the PSD. (A) Post-embedding immunogold labeling for synaptophysin (SYN), a presynaptic vesicle-associated protein, and seven postsynaptic proteins: NMDA receptor (NR2), PSD-95, neuronal nitric oxide synthase (nNOS), cysteine-rich interactor of PDZ three (CRIPT), guanylate kinase-associated protein (GKAP), Shank, and dynein light chain (DLC). (See facing page for legend.) 
with metabotropic glutamate receptors) and concentrate on the cytoplasmic side of the PSD (Petralia et al. 2005). Together, these multidomain scaffold proteins compose the structural "core" of the PSD (Chen et al. 2008).

Numerous other proteins within the PSD matrix are probably involved in downstream signaling (Kennedy et al. 2005). Enzymes for which direct immunogold evidence shows an association with the PSD include the kinases CaMKIIa and ErbB4 (Fig. 6D) (Petersen et al. 2003; Petralia et al. 2005) and the tyrosine kinase interactor liprin- $\alpha$ (Wyszynski et al. 2002); additionally, the phosphatases spinophilin, neurabin, and protein phosphatase- 1 occur in the PSD (Muly et al. 2004a,b; Bordelon et al. 2005), although these enzymes are also present in the spine cytoplasm. Several small GTPases have been implicated in synaptic function; immunogold has identified Rab family GTPases (Gerges et al. 2004; Brown et al. 2005); the small GTPase activating proteins SynGAP, GIT1, and SPAR (Ko et al. 2003; Petralia et al. 2005); and the GTPase exchange factors Tiam1 and BRAG1 (Tolias et al. 2005; Sakagami et al. 2008; Sanda et al. 2009) in the PSD; likewise, most of these are also in the spine cytoplasm. Most of these molecules appear to play a role in synaptic plasticity, as does Arc and the putative synapse-tonucleus signaling molecule AIDA-1 (Moga et al. 2004; Jacob et al. 2010). There is also immunogold evidence for several PSD-associated proteins linked to the actin cytoskeleton including $\alpha$-actinin, cofilin, and cortactin (Wyszynski et al. 1998; Racz and Weinberg 2004, 2006), as well as the dynein subunit DLC and the kinesin KIF1 (Naisbitt et al. 2000; Shin et al. 2003).

\section{Molecular Anatomy beyond the PSD}

A host of other ligand-gated receptors and channels have been identified by pre-embedding methods, mainly concentrated along the spine plasma membrane, away from the PSD (but as noted above, these methods may fail to detect protein within the PSD), including dopamine and 5-HT receptors, nicotinic acetylcholine receptors, and EphA receptors (Miner et al. 2000, 2003; Riad et al. 2000; Fabian-Fine et al. 2001; Tremblay et al. 2007; Duffy et al. 2009). New data come from the "SDS-FRL" approach (sodium dodecyl sulfate-freeze-fracture replica labeling), in which freeze-fractured tissue is coated with an inert film of platinum and carbon (to protect proteins embedded in the membrane from subsequent digestion in hot SDS, which removes tissue from the back of the platinum-carbon replica) before immunolabeling (Fig. 6E). Besides providing superior sensitivity, the SDS-FRL technique is highly specific; in fact, a number of proteins have been successfully immunolabeled only with SDS-FRL. The method provides a powerful tool for study of integral membrane proteins, such as receptors (e.g., the data shown in Fig. 6F,G are from a quantitative study showing asymmetry in glutamate receptor subtype expression at hippocampal synapses [Shinohara et al. 2008]), but

Figure 6. (Continued) (B) The diagram illustrates supramolecular organization of the PSD. Location of each ellipsoid is according to mean immunogold positions, ellipsoid volumes are proportional to the molecular weight of each protein, and contacts are shown between proteins known to interact biochemically. $(C)$ Axodendritic positions relative to the postsynaptic plasma membrane ( $0 \mathrm{~nm}$ on the $x$-axis) of gold particles coding for three of these proteins (PSD-95, CRIPT, and GKAP). (D) "Immunogold-PSD" labeling for CaMKII $\alpha$ (orange) on a biochemically isolated PSD (green) viewed en face (top) and with EM tomography from the side, where the postsynaptic membrane (PM) is at the bottom. (E) The schematic illustrates methods for SDS-FRL: Freeze-fracture follows the hydrophobic interior of the plasma membrane, and proteins pull to either the exoplasmic (E-face) or the cytoplasmic (P-face). After application of a thin platinum/carbon film, the material is digested in hot SDS, and the replicas are immunogold labeled. $(F)$ Hippocampal CA1 spine synapses in s. radiatum, labeled by SDS-FRL for the GluR1 and NR1 glutamate receptor subunits, and $(G)$ NR2B and NR1 subunits (the black line outlines the intramembranous particle aggregate in the E-face). Scale bars, $100 \mathrm{~nm}$. (Panels $A-C$ are from Valtschanoff and Weinberg 2001; reprinted, with permission, from the author; panel $D$ is from Petersen et al. 2003; reprinted, with permission, from the Journal of Neuroscience (C) 2001; panels $E-G$ are modified from Shinohara et al. 2008.) 
is unsuitable for detecting proteins beyond the plasma membrane. Both SDS-FRL and standard pre-embedding techniques have identified a variety of voltage-dependent potassium channels in spine membranes, including $\mathrm{K}_{\mathrm{V}} 1, \mathrm{~K}_{\mathrm{V}} 3$, $\mathrm{K}_{\mathrm{V}} 4, \mathrm{~K}_{\mathrm{ir}} 3, \mathrm{HCN}, \mathrm{BK}$, and TASK subtypes (Lorincz et al. 2002; Luján et al. 2003; Callahan et al. 2004; Notomi and Shigemoto 2004; Burkhalter et al. 2006; Kulik et al. 2006; Kaufmann et al. 2009; Puente et al. 2010). In addition, several transporters and pumps have been detected within the spine plasma membrane, including glutamate transporters (He et al. 2000), the calcium exchanger NCX1 (Lorincz et al. 2007), and multiple PMCA isoforms (Burette and Weinberg 2007; Burette et al. 2009, 2010; Kenyon et al. 2010). It seems likely that other pumps (e.g., the $\mathrm{Na}^{+}-\mathrm{K}^{+}$ATPase) are also present, but immunogold data are not yet available.

A number of signaling and motor-related proteins are found within the cytoplasm of the dendritic spine. There is abundant evidence, including immunogold labeling, for actin (Morales and Fifkova 1989; Korobova and Svitkina 2010) and, to a lesser degree, also for myosin (Morales and Fifkova 1989; Petralia et al. 2001). Mechanisms controlling actin remodeling within the spine are of keen interest because actin remodeling is implicated in structural neuroplasticity and defects are associated with neurodevelopmental disorders ( for review, see Carlisle and Kennedy 2005; Tada and Sheng 2006; Penzes et al. 2008; Kasai et al. 2010; Svitkina et al. 2010). Immunogold methods have identified a variety of actin-binding proteins in the spine cytoplasm, including cortactin, profilin, drebrin, and the Arp2/3 complex (Racz and Weinberg 2004, 2008; Neuhoff et al. 2005; Kobayashi et al. 2007).

\section{Molecular Anatomy of Inhibitory Postsynaptic Membranes}

$\mathrm{GABA}_{\mathrm{A}}$ receptors are typical heteropentameric ligand-gated channels. They are constituted from 19 different subunit proteins, allowing for enormous heterogeneity (Luscher and Keller 2004; Tretter and Moss 2008). Immunogold EM shows that $\mathrm{GABA}_{\mathrm{A}}$ receptors concentrate at synapses (Nusser et al. 1996; Bergersen et al. 2003;
Baude et al. 2007; Masugi-Tokita and Shigemoto 2007), but extrasynaptic receptors are also present and may be functionally significant. The number of $\mathrm{GABA}_{\mathrm{A}}$ receptors at a synapse (which varies considerably) is directly related to the magnitude of the inhibitory postsynaptic current (Nusser et al. 1997). Besides differing in functional properties, subunit composition plays a role in targeting receptors to specific types of synapses (Nyiri et al. 2001; Klausberger et al. 2002; Serwanski et al. 2006; Baude et al. 2007). The biochemically unrelated $G_{A B A}$ receptors are G-protein-coupled dimers, whose functional properties are largely determined by auxiliary subunits (Pinard et al. 2010); immunogold EM shows their presence in the plasma membrane at postsynaptic, presynaptic, and nonsynaptic locations (Gonchar et al. 2001; Luján et al. 2003; Kulik et al. 2006).

Consistent with the classical morphological descriptions of Gray type II synapses as lacking a prominent PSD, relatively few intracellular proteins have been linked to inhibitory synapses. The best known is gephyrin, which is linked to both GABAergic and glycinergic synapses (Danglot et al. 2003). Profilin and specific isoforms of GRIP associate with the $\mathrm{GABA}_{\mathrm{A}}$ receptor (Li et al. 2005; Neuhoff et al. 2005; Yu et al. 2008); the association with GRIP is striking, since GRIP is usually thought to bind selectively to AMPA receptors. Immunogold evidence that $G_{A B A}$ receptors are associated with Kir3.2 channels (Kulik et al. 2006) has direct functional implications because inwardly rectifying potassium channels are important for the normal function of these receptors.

\section{Smooth Endoplasmic Reticulum in Dendrites and Spines}

Some dendritic spines contain smooth endoplasmic reticulum (SER), a membrane-bound network that is continuous throughout the neuron. Nearly all dendritic spines in cerebellum contain SER (Fig. 7A,B), and the SER volume correlates well with total spine volume (Harris and Stevens 1988a). In contrast, $<15 \%$ of dendritic spines in hippocampus contain SER, usually only the largest spines (Fig. 7C) (Spacek and 

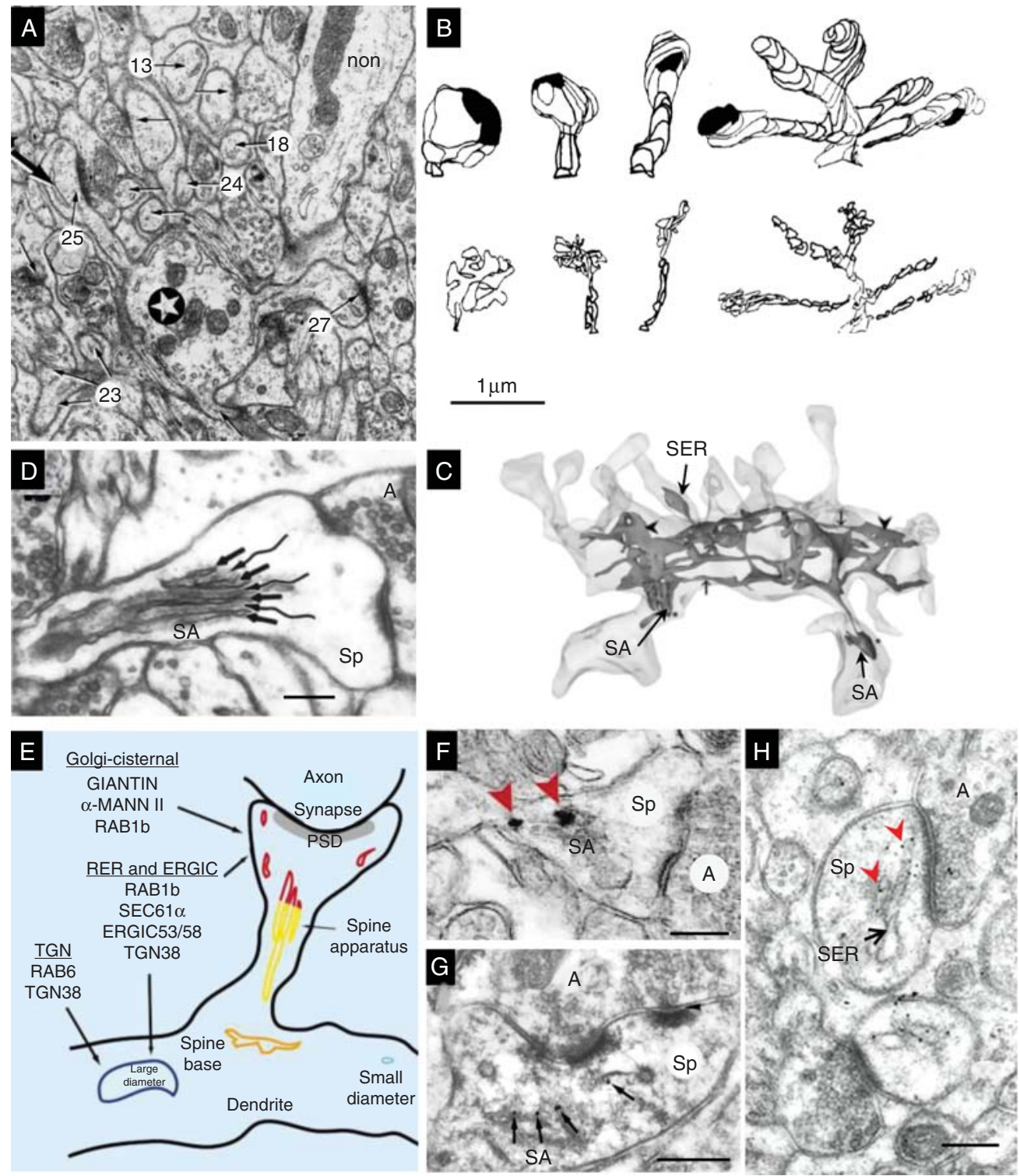

Figure 7. Dendritic SER. (A) Purkinje cell dendrite (star) and associated spines determined by serial section EM (arrows, some of which are numbered); all of these spines contain SER (e.g., large arrow in spine 25); and a nonspiny dendrite of an interneuron (non). (B) 3D reconstructions of cerebellar dendritic spines (top row, short, medium, long, and branched) and SER tubules (bottom row) illustrate close correlation between spine and SER volume. (C) 3D reconstruction of CA1 dendrite SER, which enters only three spines, two of which have a spine apparatus (SA). (D) The SA has laminated SER (arrows) interspersed with dense-staining material (wavy lines). (E) Summary diagram of Golgi- and secretory-related molecules found in SA and vesicular compartments. ( $F$ ) SA containing silver-enhanced gold labeling for giantin (red arrowheads), a protein involved in vesicle trafficking through the Golgi apparatus. $(G)$ Post-embedding immunogold labeling for synaptopodin (black arrows), an actin-associated protein, in a spine apparatus from a dendritic spine in the s. radiatum of area CA3. $(H)$ Post-embedding immunogold labeling for IP3 receptors (red arrowheads) along SER in a cerebellar spine head (Sp). Scale bar in $B$ is $1 \mu \mathrm{m}$ and applies to $A-C$. Scale bars in $D, F, G$, and $H$ are all $250 \mathrm{~nm}$. (See facing page for legend.) 
Harris 1997). The spine apparatus is an enigmatic organelle variously suggested to be involved in the regulation of calcium, synthesis of proteins, and/or posttranslational modification of proteins (Fig. 7D). It contains SER arranged in laminae separated by dense-staining bars, which contain the actin-binding protein synaptopodin (Fig. 7G) (Deller et al. 2000). The spine apparatus also contains numerous proteins, such as giantin, that are known to be involved in vesicular trafficking through the Golgi apparatus in the soma (Fig. 7E,F) (Pierce et al. 2000, 2001). The SER of cerebellar spines contains high levels of the IP3 receptor, involved in calcium signaling (Fig. 7H), unlike hippocampal and cortical dendritic spines, where IP3 receptors (as well as ryanodine receptors) are largely confined to SER in the dendritic shaft (Walton et al. 1991). Interestingly, the amount of SER varies greatly along the dendritic shaft (Fig. 7C), in proportion to the size of the spines emerging along the shaft, at least in hippocampus (Spacek and Harris 1997). Whether the uniform expression of SER in cerebellar dendritic spines might explain their relative stability, in contrast to the plasticity of hippocampal spines (Bourne and Harris 2007), remains to be determined.

\section{Polyribosomes in Dendrites and Spines}

Ribosomes are needed for local translation in dendrites (Steward and Schuman 2003; Bramham and Wells 2007) and can be found in a subset of dendritic spines (Fig. 8A). Individual ribosomes are 10-25-nm electron-dense spheres surrounded by a gray halo; they can be unambiguously identified when organized as polyribosomes that form a cluster of three or more ribosomes, but monosomes are usually not quantified because they are difficult to distinguish from other dark-staining proteins in the cytoplasm (Fig. 8B). Free polyribosomes, which synthesize cytoplasmic proteins such as CaMKII $\alpha$ and PSD-95, are more prevalent in spines after LTP-inducing stimuli (Ostroff et al. 2002; Bourne et al. 2007a; Bourne and Harris 2010). Bound polyribosomes associated with endoplasmic reticulum synthesize integral membrane proteins, including receptors. Polyribosomes can also be found in the vicinity of a spine apparatus (Fig. 8C) (see also Steward and Reeves 1988), supporting the hypothesis that the spine apparatus is a Golgi outpost, as described in the main dendritic shafts of neurons (Horton et al. 2005). The non-uniform distribution of ribosomes suggests that different degrees of local protein synthesis occur along relatively short dendritic segments, perhaps reflecting local regions of synaptic growth and plasticity.

\section{Endosomal Compartments in Dendrites and Spines}

Reconstruction of serial sections is required to distinguish the discrete tubules and vesicles of the endosomal compartments from SER. Further clarification came when recycling endosomes were shown by their uptake of gold particles conjugated with bovine serum albumin (BSA-gold) delivered in the extracellular space of hippocampal slices (Fig. 9A-D). Quantitative work shows that $\sim 50 \%$ of normal hippocampal dendritic spines contain no membranebound organelles. Some spines contain endosomes and some contain SER, but only rarely does the same spine contain both organelles; analysis of $3 \mathrm{D}$ reconstructions suggests that a single endosomal sorting complex serves about 10 to 20 hippocampal dendritic spines (Cooney et al. 2002). Interestingly, the endocytosis-related proteins clathrin, AP-2, dynamin (Fig. 9E-G) (Racz et al. 2004; Lu et al. 2007), and an isoform of the exocytosis-related protein

Figure 7. (Continued) (Panels $A$ and $B$ are from Harris and Stevens 1988a; reprinted, with permission, from the author; panel $C$ is from Cooney et al. 2002; reprinted, with permission, from the author; panel $D$ is from Spacek and Harris 1997; reprinted, with permission, from the author; panels $E$ and $F$ are from Pierce et al. 2001; reprinted, with permission, from Elsevier (C) 2001; panel $G$ is modified from Deller et al. 2000; panel $H$ is modified from Kelm et al. 2010.) 

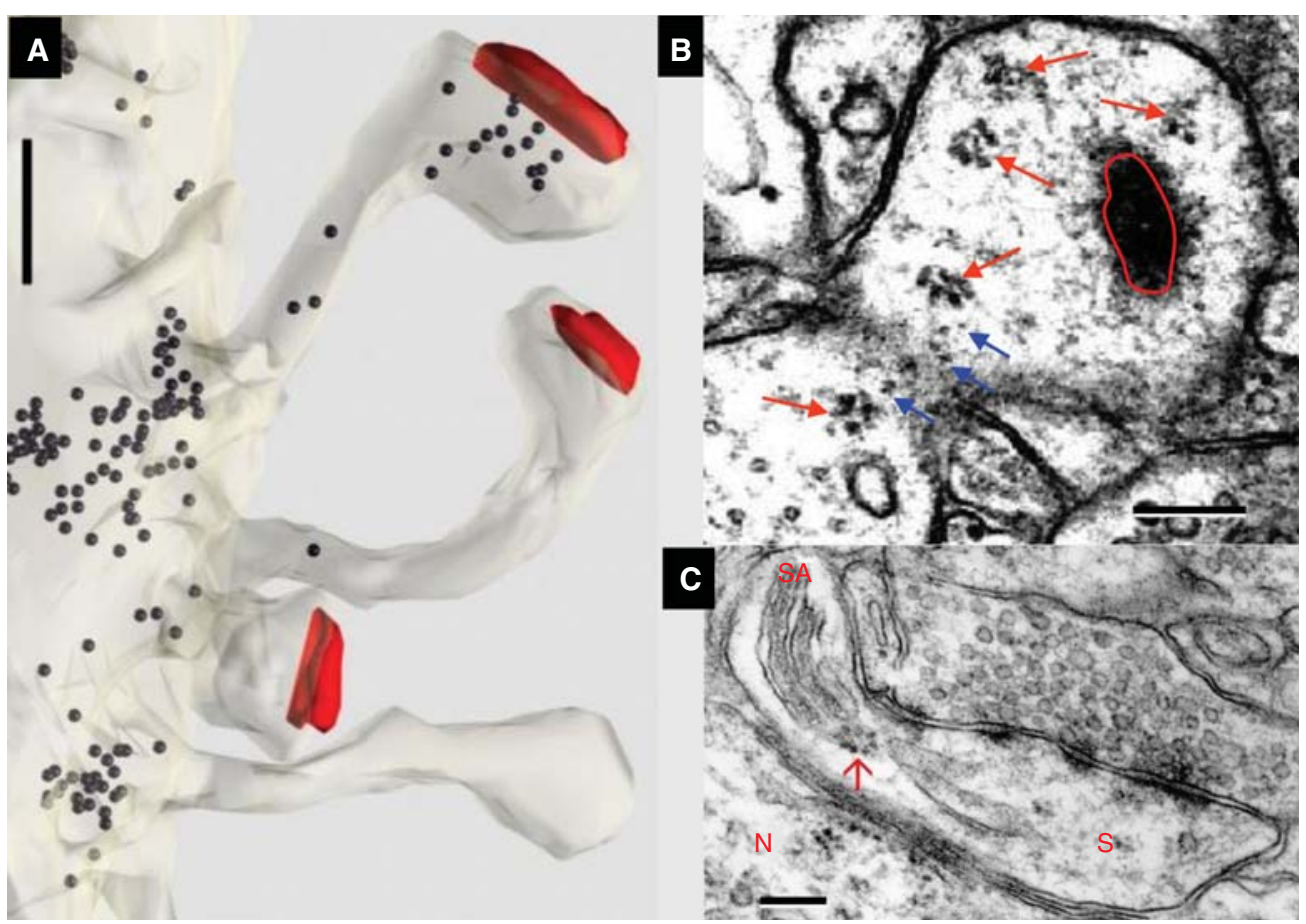

Figure 8. Ribosomes indicate sites of local protein synthesis. (A) Non-uniform distribution of ribosomes (black dots) in hippocampal CA1 dendrite and spines (red, PSD surface area). (B) Free polyribosomes (red arrows) and putative monosomes (blue arrows) in a large mushroom spine with an en face PSD (encircled in red). (C) Polyribosome (red arrow) associated with endoplasmic reticulum of a spine apparatus (SA) in a dendritic spine (S) adjacent to a neuron (N) in mouse neocortex. Scales, $200 \mathrm{~nm}$. (Panel $A$ is from http://synapses.clm.utexas.edu/ anatomy/ribosome/ribo2.stm; reprinted, with permission, from J. Spacek; panel $B$ is modified from Bourne et al. 2007a; reprinted, with permission, from the author; panel $C$ is from http://synapses.clm.utexas.edu/anatomy/ribosome/ribo3.stm; reprinted, with permission, from J. Spacek.)

syntaxin (Kennedy et al. 2010) are all localized to a putative endocytic zone lateral to the PSD. Endosomal compartments are dynamically regulated during synaptic plasticity and may provide a local source of new membrane for spine enlargement (Park et al. 2006). Some endosomal compartments in dendrites may also be involved in autophagocytosis, a process in which proteins and other structures are engulfed by a membrane-bound organelle and incorporated into the lysosomal pathway for subsequent degradation (Bingol and Sheng 2011).

\section{Trans-Endocytosis via Spinules}

Besides the classical mechanisms of synaptic communication, another path for signaling between neurons is trans-endocytosis of the plas- ma membrane via spinules (Spacek and Harris 2004; Richards et al. 2005). Spinules form when presynaptic axons engulf part of a postsynaptic dendritic spine (often in the perforation of a PSD) (Fig. 9H,I); when a neighboring axon engulfs part of the nonsynaptic membrane of the spine (Fig. 9I,J); and when perisynaptic astroglial processes engulf spinules from the nonsynaptic plasma membrane of a spine (Fig. 9J,K). Intrinsic dendritic recycling via endosomes can modify dendritic spine morphology and composition and may help to redistribute these membrane resources locally (Fig. 9L). Trans-endocytosis may also cause remodeling of dendritic spine and synapse morphology (Fig. 9M); it may also serve interneuronal signaling between dendritic spines and presynaptic or neighboring axons (Fig. 9N) and glia (Fig. 9O). 
K.M. Harris and R.J. Weinberg
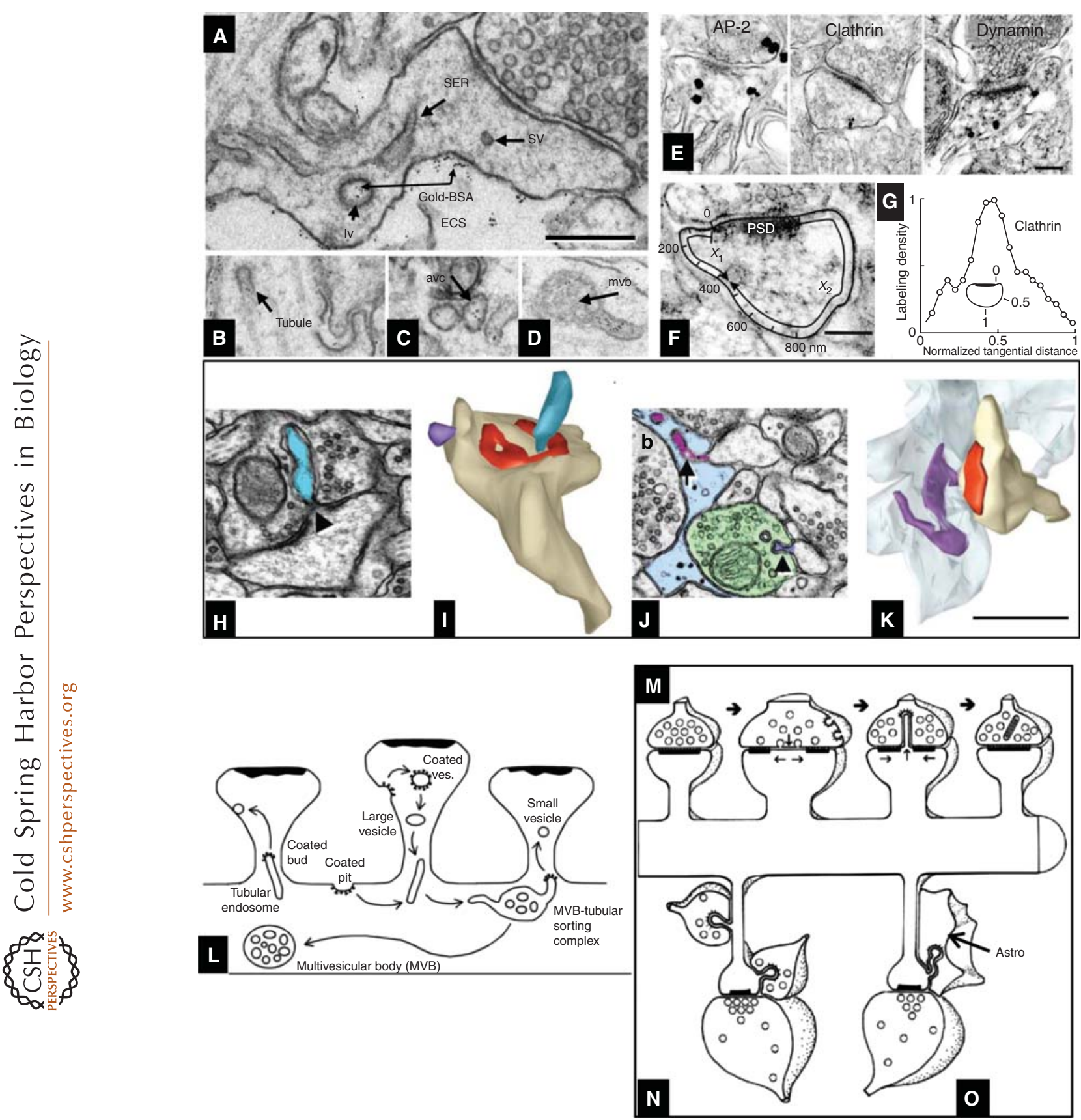

Figure 9. Endocytosis and trans-endocytosis at dendritic spines. (A) SER, small vesicles (sv), and recycling endosomes; the latter may be identified by their content of gold-BSA endocytosed from the extracellular space (ECS) into large vesicles (lv), (B) tubules, $(C)$ amorphous vesicular clumps, and $(D)$ multivesicular bodies. $(E-G)$ Silver-enhanced pre-embedding immunogold identifies three proteins (AP-2, clathrin, and dynamin) critical for endocytosis; label for all three concentrates close to the spine plasma membrane. To assess their position with respect to the synapse, the locus of each particle was projected onto the spine plasma membrane as illustrated in $F$, allowing computation of a normalized tangential distance along the plasma membrane. (See facing page for legend.) 


\section{Other Components in Dendritic Spines}

Mitochondria are crucial for generation of ATP and can be important in the regulation of $\mathrm{Ca}^{2+}$ levels and synaptic plasticity. Hence, their location may predict sites of enhanced synaptic activity (MacAskill et al. 2010). Mitochondria are present along the entire length of dendritic shafts, but rarely in simple dendritic spines, such as those found in hippocampal area CA1 or cerebellar cortex. However, mitochondria are not uncommon in very large and complex spines, such as the branched spines or "thorny excrescences" located on proximal dendrites of CA3 pyramidal cells (Chicurel and Harris 1992). In cultured hippocampal neurons, mitochondria have been observed with live imaging to enter dendritic spine-like protrusions during periods of intense synaptic remodeling ( $\mathrm{Li}$ et al. 2004).

Microtubules are crucial for trafficking organelles such as SER and vesicles, as well as for the trafficking of certain proteins and mRNAs. Tubulin has been detected in PSD fractions; however, microtubules are not readily observed through serial section electron microscopy in mature hippocampal, cortical, or cerebellar dendritic spines under normal conditions. Microtubules do occur normally in the extra-large CA3 thorny excrescences (Chicurel and Harris 1992) and in hippocampal and cortical den- dritic spines during development, apparently emanating from the spine apparatus (Westrum and Gray 1977; Westrum et al. 1980). During the short period of synaptic quiescence after making a hippocampal slice, microtubules protrude into mature dendritic spines; however, these spine microtubules are no longer detected by $30 \mathrm{~min}$ after the slice has recovered in vitro (Fiala et al. 2003). Recent work in hippocampal cultures suggests that microtubules are highly dynamic and rapidly enter and retract from dendritic spines ( $\mathrm{Gu}$ et al. 2008; Hu et al. 2008; Jaworski et al. 2009; Dent et al. 2011), such that at any one moment fewer than $1 \%$ of spines may contain a microtubule. This transience, along with the sensitivity to calcium (see "Other Axonal Components" above), may explain why microtubules are rarely detected in a polymerized state in mature dendritic spines of aldehydefixed brain in vivo.

\section{SUMMARY}

In this article, we have described the diverse structure and composition of presynaptic axons and postsynaptic spines. Postsynaptic size is proportional to presynaptic vesicle content, and larger dendritic spines contain more of the subcellular organelles needed to remodel and sustain

Figure 9. (Continued) As shown for clathrin in $G$, each of these endocytic proteins concentrated in a sector of the spine lying roughly halfway between the edge of the PSD and the point on the spine plasma membrane closest to the spine neck opposite to the PSD (illustrated as "1" in the inset) (for further description, see Racz et al. 2004). $(H)$ Spinule (blue) emerging from the middle of a perforated PSD (triangle) on a dendritic spine head; this spinule is engulfed by the plasma membrane of the presynaptic axon. (I) $3 \mathrm{D}$ reconstruction of the spinule in $H$ (blue), and also a second smaller spinule (purple) being engulfed by a neighboring axon, not shown). ( $J$ ) Spinule from a dendritic spine (purple arrow, top) being engulfed by a perisynaptic astroglial process (light blue), and a second smaller spinule from a different spine ( purple arrowhead, bottom) being engulfed by a neighboring axon (green), similar to the purple reconstruction in $I$. (K) 3D reconstruction of the astroglial-engulfed spinule shown on a single section in $J$ (spinule [ purple], astroglial process [light blue], spine [tan], PSD [red]). ( $L-O)$ Contrasting endocytosis and trans-endocytosis. $(L)$ A single MVB-tubular sorting complex in the dendritic shaft serves multiple dendritic spines, where coated pits and vesicles are endocytosed from some spines, and small vesicles bud off (also via coats) from tubular endosomes, to be exocytosed at the plasma membrane of neighboring spines. $(M)$ Trans-endocytosis from a spine to the presynaptic axon may serve to transmit signaling molecules or to remove perforations following sustained presynaptic activation. $(N)$ Trans-endocytosis by neighboring axons may reflect competition for the postsynaptic spine. $(O)$ The function of trans-endocytosis by neighboring astroglial processes is unknown. Scales, $(A-D, H-K) 500 \mathrm{~nm}$; $(E, F) 200 \mathrm{~nm}$. (Panels $A-D$ and $L$ are from Cooney et al. 2002; reprinted, with permission, from the authors; panels $E-G$ are from Racz et al. 2004; reprinted, with permission, from the authors; and panels $H-K$ and $M-O$ are from Spacek and Harris 2004; reprinted, with permission, from the authors.) 
K.M. Harris and R.J. Weinberg

synapses. Synaptic structure is static in electron micrographs, but accumulating evidence shows that the synapse is highly dynamic in vivo, undergoing dramatic changes in gross morphology and intracellular organization, especially in response to conditions that elicit sustained changes in synaptic efficacy. The structure and composition of synapses can vary across brain regions and may change during development, maturation, normal aging, neurological disorders, and trauma. A deeper appreciation of this structural diversity and plasticity is leading to new insight into the processes that govern synapse formation, growth, maintenance, and elimination, topics that will be pursued in other articles in this collection.

\section{REFERENCES}

Ahmari SE, Smith SJ. 2002. Knowing a nascent synapse when you see it. Neuron 34: 333-336.

Amaral DG, Dent JA. 1981. Development of the mossy fibers of the dentate gyrus: I. A light and electron microscopic study of the mossy fibers and their expansions. J Comp Neurol 195: 51-86.

Arellano JI, Benavides-Piccione R, DeFelipe J, Yuste R. 2007. Ultrastructure of dendritic spines: Correlation between synaptic and spine morphologies. Frontiers Neurosci 1: 131-143.

Balaji J, Ryan TA. 2007. Single-vesicle imaging reveals that synaptic vesicle exocytosis and endocytosis are coupled by a single stochastic mode. Proc Natl Acad Sci 104: 20576-20581.

Baude A, Bleasdale C, Dalezios Y, Somogyi P, Klausberger T. 2007. Immunoreactivity for the $\mathrm{GABA}_{\mathrm{A}}$ receptor $\alpha 1$ subunit, somatostatin and Connexin36 distinguishes axoaxonic, basket, and bistratified interneurons of the rat hippocampus. Cereb Cortex 17: 2094-2107.

Bauerfeind R, Jelinek R, Hellwig A, Huttner WB. 1995. Neurosecretory vesicles can be hybrids of synaptic vesicles and secretory granules. Proc Natl Acad Sci 92: $7342-$ 7346.

Bergersen L, Ruiz A, Bjaalie JG, Kullmann DM, Gundersen V. 2003. GABA and $G_{A B A}$ receptors at hippocampal mossy fibre synapses. Eur J Neurosci 18: 931-941.

Bingol B, Sheng M. 2011. Deconstruction for reconstruction: The role of proteolysis in neural plasticity and disease. Neuron 69: 22-32.

Bloom O, Evergren E, Tomilin N, Kjaerulff O, Low P, Brodin L, Pieribone VA, Greengard P, Shupliakov O. 2003. Colocalization of synapsin and actin during synaptic vesicle recycling. J Cell Biol 161: 737-747.

Bordelon JR, Smith Y, Nairn AC, Colbran RJ, Greengard P, Muly EC. 2005. Differential localization of protein phosphatase- $1 \alpha, \beta$ and $\gamma 1$ isoforms in primate prefrontal cortex. Cereb Cortex 15: 1928-1937.
Bourne J, Harris KM. 2007. Do thin spines learn to be mushroom spines that remember? Curr Opin Neurobiol 17: 381-386.

Bourne JN, Harris KM. 2010. Coordination of size and number of excitatory and inhibitory synapses results in a balanced structural plasticity along mature hippocampal CA1 dendrites during LTP. Hippocampus 21: 354-373.

Bourne JN, Sorra KE, Hurlburt J, Harris KM. 2007a. Polyribosomes are increased in spines of CA1 dendrites $2 \mathrm{~h}$ after the induction of LTP in mature rat hippocampal slices. Hippocampus 17: 1-4.

Bourne JN, Kirov SA, Sorra KE, Harris KM. 2007b. Warmer preparation of hippocampal slices prevents synapse proliferation that might obscure LTP-related structural plasticity. Neuropharmacology 52: 55-59.

Bramham CR, Wells DG. 2007. Dendritic mRNA: Transport, translation and function. Nat Rev Neurosci 8: 776789.

Brodin L, Shupliakov O. 2006. Giant reticulospinal synapse in lamprey: Molecular links between active and periactive zones. Cell Tissue Res 326: 301-310.

Brown TC, Tran IC, Backos DS, Esteban JA. 2005. NMDA receptor-dependent activation of the small GTPase Rab5 drives the removal of synaptic AMPA receptors during hippocampal LTD. Neuron 45: 81-94.

Buchert M, Schneider, Meskenaite V, Adams MT, Canaani E, Baechi T, Moelling K, Hovens CM. 1999. The junctionassociated protein AF-6 interacts and clusters with specific Eph receptor tyrosine kinases at specialized sites of cell-cell contact in the brain. J Cell Biol 144: 361-371.

Burette A, Weinberg RJ. 2007. Perisynaptic organization of plasma membrane calcium pumps in cerebellar cortex. J Comp Neurol 500: 1127-1135.

Burette A, Khatri L, Wyszynski M, Sheng M, Ziff EB, Weinberg RJ. 2001. Differential cellular and subcellular localization of AMPA receptor-binding protein and glutamate receptor-interacting protein. J Neurosci 21: 495-503.

Burette AC, Strehler EE, Weinberg RJ. 2009. "Fast" plasma membrane calcium pump PMCA2a concentrates in GABAergic terminals in the adult rat brain. J Comp Neurol 512: 500-513.

Burette AC, Strehler EE, Weinberg RJ. 2010. A plasma membrane $\mathrm{Ca}^{2+}$ ATPase isoform at the postsynaptic density. Neurosci 169: 987-993.

Burkhalter A, Gonchar Y, Mellor RL, Nerbonne JM. 2006. Differential expression of I(A) channel subunits Kv4.2 and $\mathrm{Kv} 4.3$ in mouse visual cortical neurons and synapses. J Neurosci 26: 12274-12282.

Callahan R, Labunskiy DA, Logvinova A, Abdallah M, Liu C, Cotton JF, Yost CS. 2004. Immunolocalization of TASK-3 (KCNK9) to a subset of cortical neurons in the rat CNS. Biochem Biophys Res Commun 319: 525-530.

Carlisle HJ, Kennedy MB. 2005. Spine architecture and synaptic plasticity. Trends Neurosci 28: 182-187.

Chen W, Aoki C, Mahadomrongkul V, Gruber CE, Wang GJ, Blitzblau R, Irwin N, Rosenberg PA. 2002. Expression of a variant form of the glutamate transporter GLT1 in neuronal cultures and in neurons and astrocytes in the rat brain. J Neurosci 22: 2142-2152.

Chen X, Vinade L, Leapman RD, Petersen JD, Nakagawa T, Phillips TM, Sheng M, Reese TS. 2005. Mass of the 
postsynaptic density and enumeration of three key molecules. Proc Natl Acad Sci 102: 11551-11556.

Chen X, Winters C, Azzam R, Li X, Galbraith JA, Leapman RD, Reese TS. 2008. Organization of the core structure of the postsynaptic density. Proc Natl Acad Sci 105: 44534458.

Chicurel ME, Harris KM. 1992. Three-dimensional analysis of the structure and composition of CA3 branched dendritic spines and their synaptic relationships with mossy fiber boutons in the rat hippocampus. J Comp Neurol 325: $169-182$.

Chicurel ME, Terrian DM, Potter H. 1993. mRNA at the synapse: Analysis of a synaptosomal preparation enriched in hippocampal dendritic spines. J Neurosci 13: 4054-4063.

Choi J, Ko J, Racz B, Burette A, Lee JR, Kim S, Na M, Lee HW, Kim K, Weinberg RJ, et al. 2005. Regulation of dendritic spine morphogenesis by insulin receptor substrate 53 , a downstream effector of Rac1 and Cdc42 small GTPases. J Neurosci 25: 869-879.

Clayton EL, Cousin MA. 2009. The molecular physiology of activity-dependent bulk endocytosis of synaptic vesicles. J Neurochem 111: 901-914.

Colonnier M. 1968. Synaptic patterns on different cell types in the different laminae of the cat visual cortex. An electron microscope study. Brain Res 9: 268-287.

Cooney JR, Hurlburt JL, Selig DK, Harris KM, Fiala JC. 2002. Endosomal compartments serve multiple hippocampal dendritic spines from a widespread rather than a local store of recycling membrane. J Neurosci 22: 22152224.

Craig AM, Kang Y. 2007. Neurexin-neuroligin signaling in synapse development. Curr Opin Neurobiol 17: 43-52.

Crispino M, Kaplan BB, Martin R, Alvarez J, Chun JT, Benech JC, Giuditta A. 1997. Active polysomes are present in the large presynaptic endings of the synaptosomal fraction from squid brain. J Neurosci 17: 7694-7702.

Crivellato E, Nico B, Ribatti D. 2005. Ultrastructural evidence of piecemeal degranulation in large dense-core vesicles of brain neurons. Anat Embryol (Berl) 210: 25-34.

Dalva MB, McClelland AC, Kayser MS. 2007. Cell adhesion molecules: Signalling functions at the synapse. Nat Rev Neurosci 8: 206-220.

Danglot L, Triller A, Bessis A. 2003. Association of gephyrin with synaptic and extrasynaptic $\mathrm{GABA}_{\mathrm{A}}$ receptors varies during development in cultured hippocampal neurons. Mol Cell Neurosci 23: 264-278.

Dani A, Huang B, Bergan J, Dulac C, Zhuang X. 2010. Superresolution imaging of chemical synapses in the brain. Neuron 68: 843-856.

Darstein M, Petralia RS, Swanson GT, Wenthold RJ, Heinemann SF. 2003. Distribution of kainate receptor subunits at hippocampal mossy fiber synapses. J Neurosci 23: 8013-8019.

DeGiorgis JA, Galbraith JA, Dosemeci A, Chen X, Reese TS. 2006. Distribution of the scaffolding proteins PSD-95, PSD-93, and SAP97 in isolated PSDs. Brain Cell Biol 35: $239-250$.

Dehay C, Douglas RJ, Martin KA, Nelson C. 1991. Excitation by geniculocortical synapses is not "vetoed" at the level of dendritic spines in cat visual cortex. J Physiol 440: $723-734$.
Deller T, Merten T, Roth SU, Mundel P, Frotscher M. 2000. Actin-associated protein synaptopodin in the rat hippocampal formation: Localization in the spine neck and close association with the spine apparatus of principal neurons. J Comp Neurol 418: 164-181.

Dent EW, Merriam EB, Hu X. 2011. The dynamic cytoskeleton: Backbone of dendritic spine plasticity. Curr Opin Neurobiol 21: 175-181.

De Robertis ED, Bennett HS. 1955. Some features of the submicroscopic morphology of synapses in frog and earthworm. J Biophys Biochem Cytol 1: 47-58.

Dityatev A, Bukalo O, Schachner M. 2008. Modulation of synaptic transmission and plasticity by cell adhesion and repulsion molecules. Neuron Glia Biol 4: 197-209.

Dityatev A, Schachner M, Sonderegger P. 2010. The dual role of the extracellular matrix in synaptic plasticity and homeostasis. Nat Rev Neurosci 11: 735-746.

Donohue HS, Gabbott PLA, Davies HA, Rodriguez JJ, Cordero MI, Sandi C, Medvedev NI, Popov VI, Colyer FM, Peddie CJ, et al. 2006. Chronic restraint stress induces changes in synapse morphology in stratum launosummoleculare CA1 rat hippocampus: A stereological and three-dimensional ultrastructural study. Neuroscience 140: 597-606.

Doussau F, Augustine GJ. 2000. The actin cytoskeleton and neurotransmitter release: An overview. Biochimie 82: 353-363.

Duffy AM, Zhou P, Milner TA, Pickel VM. 2009. Spatial and intracellular relationships between the $\alpha 7$ nicotinic acetylcholine receptor and the vesicular acetylcholine transporter in the prefrontal cortex of rat and mouse. Neurosci 161: 1091-1103.

Ehrlich I, Malinow R. 2004. Postsynaptic density 95 controls AMPA receptor incorporation during long-term potentiation and experience-driven synaptic plasticity. J Neurosci 24: 916-927.

Eyman M, Cefaliello C, Ferrara E, De Stefano R, Lavina ZS, Crispino M, Squillace A, van MJ, Kaplan BB, Giuditta A. 2007. Local synthesis of axonal and presynaptic RNA in squid model systems. Eur J Neurosci 25: 341-350.

Fabian-Fine R, Skehel P, Errington ML, Davies HA, Sher E, Stewart MG, Fine A. 2001. Ultrastructural distribution of the $\alpha 7$ nicotinic acetylcholine receptor subunit in rat hippocampus. J Neurosci 21: 7993-8003.

Fannon AM, Colman DR. 1996. A model for central synaptic junctional complex formation based on the differential adhesive specificities of the cadherins. Neuron 17: $423-434$.

Feng W, Zhang M. 2009. Organization and dynamics of PDZ-domain-related supramodules in the postsynaptic density. Nat Rev Neurosci 10: 87-99.

Fernandez-Busnadiego R, Zuber B, Maurer UE, Cyrklaff M, Baumeister W, Lucic V. 2010. Quantitative analysis of the native presynaptic cytomatrix by cryoelectron tomography. J Cell Biol 188: 145-156.

Fiala JC, Kirov SA, Feinberg MD, Petrak LJ, George P, Goddard CA, Harris KM. 2003. Timing of neuronal and glial ultrastructure disruption during brain slice preparation and recovery in vitro. J Comp Neurol 465: 90-103.

Fukaya M, Watanabe M. 2000. Improved immunohistochemical detection of postsynaptically located PSD-95/ 
K.M. Harris and R.J. Weinberg

SAP90 protein family by protease section pretreatment: A study in the adult mouse brain. J Comp Neurol 426: $572-586$.

Fukaya M, Tsujita M, Yamazaki M, Kushiya E, Abe M, Akashi K, Natsume R, Kano M, Kamiya H, Watanabe M, et al. 2006. Abundant distribution of TARP $\gamma-8$ in synaptic and extrasynaptic surface of hippocampal neurons and its major role in AMPA receptor expression on spines and dendrites. Eur J Neurosci 24: 2177-2190.

Furness DN, Dehnes Y, Akhtar AQ, Rossi DJ, Hamann M, Grutle NJ, Gundersen V, Holmseth S, Lehre KP, Ullensvang $\mathrm{K}$, et al. 2008. A quantitative assessment of glutamate uptake into hippocampal synaptic terminals and astrocytes: New insights into a neuronal role for excitatory amino acid transporter 2 (EAAT2). Neurosci 157: 80-94.

Fux CM, Krug M, Dityatev A, Schuster T, Schachner M. 2003. NCAM180 and glutamate receptor subtypes in potentiated spine synapses: An immunogold electron microscopic study. Mol Cell Neurosci 24: 939-950.

Gerges NZ, Backos DS, Esteban JA. 2004. Local control of AMPA receptor trafficking at the postsynaptic terminal by a small GTPase of the Rab family. J Biol Chem 279: 43870-43878.

Gerrow K, El-Husseini A. 2006. Cell adhesion molecules at the synapse. Front Biosci 11: 2400-2419.

Gonchar Y, Pang L, Malitschek B, Bettler B, Burkhalter A 2001. Subcellular localization of $\mathrm{GABA}_{\mathrm{B}}$ receptor subunits in rat visual cortex. J Comp Neurol 431: 182-197.

Gray EG. 1959. Axo-somatic and axo-dendritic synapses of the cerebral cortex: An electron microscope study. J Anat 93: $420-433$.

Gray EG. 1963. Electron microscopy of presynaptic organelles of the spinal cord. J Anat 97: 101-106.

Gray EG. 1975. Presynaptic microtubules and their association with synaptic vesicles. Proc R Soc Lond B Biol Sci 190: 367-372.

Gray EG, Burgoyne RD, Westrum LE, Cumming R, Barron J. 1982. The enigma of microtubule coils in brain synaptosomes. Proc R Soc Lond B Biol Sci 216: 385-396.

$\mathrm{Gu}$ J, Firestein BL, Zheng JQ. 2008. Microtubules in dendritic spine development. J Neurosci 28: 12120-12124.

Guillery RW. 2005. Observations of synaptic structures: Origins of the neuron doctrine and its current status. Philos Trans R Soc Lond B Biol Sci 360: 1281-1307.

Gulley RL, Reese TS. 1981. Cytoskeletal organization at the postsynaptic complex. J Cell Biol 91: 298-302.

Hagiwara A, Fukazawa Y, Deguchi-Tawarada M, Ohtsuka T, Shigemoto R. 2005. Differential distribution of releaserelated proteins in the hippocampal CA3 area as revealed by freeze-fracture replica labeling. J Comp Neurol 489: $195-216$.

Haglerod C, Kapic A, Boulland JL, Hussain S, Holen T, Skare O, Laake P, Ottersen OP, Haug FM, Davanger S. 2009. Protein interacting with $\mathrm{C}$ kinase 1 (PICK1) and GluR2 are associated with presynaptic plasma membrane and vesicles in hippocampal excitatory synapses. Neurosci 158: $242-252$.

Harris KM, Stevens JK. 1988a. Dendritic spines of rat cerebellar Purkinje cells: Serial electron microscopy with reference to their biophysical characteristics. J Neurosci 8: $4455-4469$.

Harris KM, Stevens JK. 1988b. Study of dendritic spines by serial electron microscopy and three-dimensional reconstructions. In Intrinsic determinants of neuronal form and function: Neurology and neurobiology (ed. Lasek RJ, Black MM), Vol. 37, pp. 179-199. Alan R. Liss, New York.

Harris KM, Stevens JK. 1989. Dendritic spines of CA 1 pyramidal cells in the rat hippocampus: Serial electron microscopy with reference to their biophysical characteristics. J Neurosci 9: 2982-2997.

Harris KM, Sultan P. 1995. Variation in the number, location and size of synaptic vesicles provides an anatomical basis for the nonuniform probability of release at hippocampal CA1 synapses. Neuropharmacology 34: 1387-1395.

Harris KM, Cruce WL, Greenough WT, Teyler TJ. 1980. A Golgi impregnation technique for thin brain slices maintained in vitro. J Neurosci Methods 2: 363-371.

Harris KM, Marshall PE, Landis DM. 1985. Ultrastructural study of cholecystokinin-immunoreactive cells and processes in area CA1 of the rat hippocampus. J Comp Neurol 233: $147-158$.

He Y, Janssen WG, Rothstein JD, Morrison JH. 2000. Differential synaptic localization of the glutamate transporter EAAC1 and glutamate receptor subunit GluR2 in the rat hippocampus. J Comp Neurol 418: 255-269.

Henze DA, McMahon DB, Harris KM, Barrionuevo G. 2002. Giant miniature EPSCs at the hippocampal mossy fiber to CA3 pyramidal cell synapse are monoquantal. $J$ Neurophysiol 87: 15-29.

Heuser JE, Reese TS. 1977. Structure of the synapse. In The handbook of physiology, the nervous system I (ed. Kandel E), pp. 261-294. American Physiological Society, Bethesda, MD.

Hirokawa N. 1989. The arrangement of actin filaments in the postsynaptic cytoplasm of the cerebellar cortex revealed by quick-freeze deep-etch electron microscopy. Neurosci Res 6: 269-275.

Horton AC, Racz B, Monson EE, Lin AL, Weinberg RJ, Ehlers MD. 2005. Polarized secretory trafficking directs cargo for asymmetric dendrite growth and morphogenesis. Neuron 48: 757-771.

Hsueh YP, Yang FC, Kharazia V, Naisbitt S, Cohen AR, Weinberg RJ, Sheng M. 1998. Direct interaction of CASK/ LIN-2 and syndecan heparan sulfate proteoglycan and their overlapping distribution in neuronal synapses. J Cell Biol 142: 139-151.

Hu BR, Park M, Martone ME, Fischer WH, Ellisman MH, Zivin JA. 1998. Assembly of proteins to postsynaptic densities after transient cerebral ischemia. J Neurosci 18: 625-633.

$\mathrm{Hu} \mathrm{H}$, Shao LR, Chavoshy S, Gu N, Trieb M, Behrens R, Laake P, Pongs O, Knaus HG, Ottersen OP, et al. 2001. Presynaptic $\mathrm{Ca}^{2+}$-activated $\mathrm{K}^{+}$channels in glutamatergic hippocampal terminals and their role in spike repolarization and regulation of transmitter release. J Neurosci 21: 9585-9597.

Hu X, Viesselmann C, Nam S, Merriam E, Dent EW. 2008. Activity-dependent dynamic microtubule invasion of dendritic spines. J Neurosci 28: 13094-13105. 
Huntley GW, Elste AM, Patil SB, Bozdagi O, Benson DL, Steward O. 2010. Synaptic loss and retention of different classic cadherins with LTP-associated synaptic structural remodeling in vivo. Hippocampus doi: 10.1002/hipo. 20859 .

Jacob AL, Jordan BA, Weinberg RJ. 2010. Organization of amyloid- $\beta$ protein precursor intracellular domain-associated protein-1 in the rat brain. J Comp Neurol 518: 3221-3236.

Jaworski J, Kapitein LC, Gouveia SM, Dortland BR, Wulf PS, Grigoriev I, Camera P, Spangler SA, Di SP, Demmers J, et al. 2009. Dynamic microtubules regulate dendritic spine morphology and synaptic plasticity. Neuron 61: 85-100.

Kasai H, Fukuda M, Watanabe S, Hayashi-Takagi A, Noguchi J. 2010. Structural dynamics of dendritic spines in memory and cognition. Trends Neurosci 33: 121-129.

Kasugai Y, Swinny JD, Roberts JD, Dalezios Y, Fukazawa Y, Sieghart W, Shigemoto R, Somogyi P. 2010. Quantitative localisation of synaptic and extrasynaptic $\mathrm{GABA}_{\mathrm{A}}$ receptor subunits on hippocampal pyramidal cells by freeze-fracture replica immunolabelling. Eur J Neurosci 32: $1868-1888$.

Kaufmann WA, Ferraguti F, Fukazawa Y, Kasugai Y, Shigemoto R, Laake P, Sexton JA, Ruth P, Wietzorrek G, Knaus HG, et al. 2009. Large-conductance calcium-activated potassium channels in Purkinje cell plasma membranes are clustered at sites of hypolemmal microdomains. J Comp Neurol 515: 215-230.

Kelm MK, Weinberg RJ, Criswell HE, Breese GR. 2010. PLC/ IP $3 \mathrm{R} / \mathrm{PKC}$ pathway is required for ethanol-enhanced GABA release. Neuropharmacology 58: 1179-1186.

Kennedy MB. 2000. Signal-processing machines at the postsynaptic density. Science 290: 750-754.

Kennedy MB, Beale HC, Carlisle HJ, Washburn LR. 2005. Integration of biochemical signalling in spines. Nat Rev Neurosci 6: 423-434.

Kennedy MJ, Davison IG, Robinson CG, Ehlers MD. 2010. Syntaxin-4 defines a domain for activity-dependent exocytosis in dendritic spines. Cell 141: 524-535.

Kenyon KA, Bushong EA, Mauer AS, Strehler EE, Weinberg RJ, Burette AC. 2010. Cellular and subcellular localization of the neuron-specific plasma membrane calcium ATPase PMCA1a in the rat brain. J Comp Neurol 518: 3169-3183.

Kharazia VN, Weinberg RJ. 1997. Tangential synaptic distribution of NMDA and AMPA receptors in rat neocortex. Neurosci Lett 238: 41-44.

Kharazia VN, Weinberg RJ. 1999. Immunogold localization of AMPA and NMDA receptors in somatic sensory cortex of albino rat. J Comp Neurol 412: 292-302.

Kim E, Sheng M. 2004. PDZ domain proteins of synapses. Nat Rev Neurosci 5: 771-781.

Kim S, Burette A, Chung HS, Kwon SK, Woo J, Lee HW, Kim K, Kim H, Weinberg RJ, Kim E. 2006. NGL family PSD95-interacting adhesion molecules regulate excitatory synapse formation. Nat Neurosci 9: 1294-1301.

Kirov SA, Sorra KE, Harris KM. 1999. Slices have more synapses than perfusion-fixed hippocampus from both young and mature rats. J Neurosci 19: 2876-2886.

Kirov SA, Petrak LJ, Fiala JC, Harris KM. 2004. Dendritic spines disappear with chilling but proliferate excessively upon rewarming of mature hippocampus. Neurosci 127: 69-80.

Klausberger T, Roberts JD, Somogyi P. 2002. Cell type- and input-specific differences in the number and subtypes of synaptic $\mathrm{GABA}_{\mathrm{A}}$ receptors in the hippocampus. J Neurosci 22: 2513-2521.

Knott GW, Quairiaux C, Genoud C, Welker E. 2002. Formation of dendritic spines with GABAergic synapses induced by whisker stimulation in adult mice. Neuron 34: 265-273.

Knott GW, Holtmaat A, Wilbrecht L, Welker E, Svoboda K. 2006. Spine growth precedes synapse formation in the adult neocortex in vivo. Nat Neurosci 9: 1117-1124.

Ko J, Kim S, Valtschanoff JG, Shin H, Lee JR, Sheng M, Premont RT, Weinberg RJ, Kim E. 2003. Interaction between liprin- $\alpha$ and GIT1 is required for AMPA receptor targeting. J Neurosci 23: 1667-1677.

Kobayashi C, Aoki C, Kojima N, Yamazaki H, Shirao T. 2007. Drebrin a content correlates with spine head size in the adult mouse cerebral cortex. J Comp Neurol 503: 618626.

Korobova F, Svitkina T. 2010. Molecular architecture of synaptic actin cytoskeleton in hippocampal neurons reveals a mechanism of dendritic spine morphogenesis. Mol Biol Cell 21: 165-176.

Kulik A, Nakadate K, Hagiwara A, Fukazawa Y, Lujan R, Saito H, Suzuki N, Futatsugi A, Mikoshiba K, Frotscher $\mathrm{M}$, et al. 2004. Immunocytochemical localization of the $\alpha 1$ A subunit of the P/Q-type calcium channel in the rat cerebellum. Eur J Neurosci 19: 2169-2178.

Kulik A, Vida I, Fukazawa Y, Guetg N, Kasugai Y, Marker CL, Rigato F, Bettler B, Wickman K, Frotscher M, et al. 2006. Compartment-dependent colocalization of Kir3.2-containing $\mathrm{K}^{+}$channels and $\mathrm{GABA}_{\mathrm{B}}$ receptors in hippocampal pyramidal cells. Neurosci 26: 4289-4297.

Ladera C, del Carmen GM, Jose CM, Torres M, Watanabe M, Lujan R, Sanchez-Prieto J. 2008. Pre-synaptic GABA receptors inhibit glutamate release through GIRK channels in rat cerebral cortex. J Neurochem 107: 1506-1517.

Landis DM, Reese TS. 1983. Cytoplasmic organization in cerebellar dendritic spines. J Cell Biol 97: 1169-1178.

Landis DM, Hall AK, Weinstein LA, Reese TS. 1988. The organization of cytoplasm at the presynaptic active zone of a central nervous system synapse. Neuron 1: 201-209.

Latefi NS, Colman DR. 2007. The CNS synapse revisited: Gaps, adhesive welds, and borders. Neurochem Res 32: 303-310.

Lawrence JJ, McBain CJ. 2003. Interneuron diversity series: Containing the detonation-feedforward inhibition in the CA3 hippocampus. Trends Neurosci 26: 631-640.

Ledoux VA, Woolley CS. 2005. Evidence that disinhibition is associated with a decrease in number of vesicles available for release at inhibitory synapses. J Neurosci 25: 971-976.

Li Z, Okamoto K, Hayashi Y, Sheng M. 2004. The importance of dendritic mitochondria in the morphogenesis and plasticity of spines and synapses. Cell 119: 873-887.

Li RW, Serwanski DR, Miralles CP, Li X, Charych E, Riquelme R, Huganir RL, De Blas AL. 2005. GRIP1 in GABAergic synapses. J Comp Neurol 488: 11-27.

Li Y, Serwanski DR, Miralles CP, Fiondella CG, Loturco JJ, Rubio ME, De Blas AL. 2010. Synaptic and nonsynaptic 
K.M. Harris and R.J. Weinberg

localization of protocadherin- $\gamma \mathrm{C} 5$ in the rat brain. $J$ Comp Neurol 518: 3439-3463.

Lisman J, Harris KM. 1993. Quantal analysis and synaptic anatomy - integrating two views of hippocampal plasticity. Trends Neurosci 16: 141-147.

LoGiudice L, Matthews G. 2009. The role of ribbons at sensory synapses. Neuroscientist 15: 380-391.

Lorincz A, Notomi T, Tamas G, Shigemoto R, Nusser Z. 2002. Polarized and compartment-dependent distribution of HCN1 in pyramidal cell dendrites. Nat Neurosci 5: 1185-1193.

Lorincz A, Rozsa B, Katona G, Vizi ES, Tamas G. 2007. Differential distribution of NCX1 contributes to spinedendrite compartmentalization in CA1 pyramidal cells. Proc Natl Acad Sci 104: 1033-1038.

Lu J, Helton TD, Blanpied TA, Racz B, Newpher TM, Weinberg RJ, Ehlers MD. 2007. Postsynaptic positioning of endocytic zones and AMPA receptor cycling by physical coupling of dynamin-3 to Homer. Neuron 55: 874-889.

Lu H, Esquivel AV, Bower JM. 2009. 3D electron microscopic reconstruction of sements of rat cerebellar purkinje cell dendrites receiving ascending and parallel fiber granule cell synaptic inputs. J Comp Neurol 514: 583-594.

Lucic V, Yang T, Schweikert G, Forster F, Baumeister W. 2005. Morphological characterization of molecular complexes present in the synaptic cleft. Structure 13: 423-434.

Luján R, Nusser Z, Roberts JD, Shigemoto R, Somogyi P. 1996. Perisynaptic location of metabotropic glutamate receptors mGluR 1 and mGluR5 on dendrites and dendritic spines in the rat hippocampus. Eur J Neurosci 8: $1488-1500$.

Luján R, de Cabo de la Vega C, Dominguez del Toro E, Ballesta JJ, Criado M, Juiz JM. 2003. Immunohistochemical localization of the voltage-gated potassium channel subunit Kv1.4 in the central nervous system of the adult rat. J Chem Neuroanat 26: 209-224.

Luscher B, Keller CA. 2004. Regulation of $\mathrm{GABA}_{\mathrm{A}}$ receptor trafficking, channel activity, and functional plasticity of inhibitory synapses. Pharmacol Ther 102: 195-221.

MacAskill AF, Atkin TA, Kittler JT. 2010. Mitochondrial trafficking and the provision of energy and calcium buffering at excitatory synapses. Eur J Neurosci 32: 231-240.

Masugi-Tokita M, Shigemoto R. 2007. High-resolution quantitative visualization of glutamate and GABA receptors at central synapses. Curr Opin Neurobiol 17: 387-393.

Megías M, Emri Z, Freund TF, Gulyás AI. 2001. Total number and distribution of inhibitory and excitatory synapses on hippocampal CA1 pyramidal cells. Neuroscience 102: 527-540.

Melone M, Bellesi M, Conti F. 2009. Synaptic localization of GLT-1a in the rat somatic sensory cortex. Glia 57: 108117.

Miner LH, Schroeter S, Blakely RD, Sesack SR. 2000. Ultrastructural localization of the serotonin transporter in superficial and deep layers of the rat prelimbic prefrontal cortex and its spatial relationship to dopamine terminals. J Comp Neurol 427: 220-234.

Miner LH, Schroeter S, Blakely RD, Sesack SR. 2003. Ultrastructural localization of the norepinephrine transporter in superficial and deep layers of the rat prelimbic prefron- tal cortex and its spatial relationship to probable dopamine terminals. J Comp Neurol 466: 478-494.

Mishchenko Y, Hu T, Spacek J, Mendenhall J, Harris KM, Chklovskii DB. 2010. Ultrastructural analysis of hippocampal neuropil from the connectomics perspective. Neuron 67: 1009-1020.

Mizoguchi A, Nakanishi H, Kimura K, Matsubara K, OzakiKuroda K, Katata T, Honda T, Kiyohara Y, Heo K, Higashi M, et al. 2002. Nectin: An adhesion molecule involved in formation of synapses. J Cell Biol 156: 555-565.

Moga DE, Calhoun ME, Chowdhury A, Worley P, Morrison JH, Shapiro ML. 2004. Activity-regulated cytoskeletal-associated protein is localized to recently activated excitatory synapses. Neurosci 125: 7-11.

Morales M, Fifkova E. 1989. In situ localization of myosin and actin in dendritic spines with the immunogold technique. J Comp Neurol 279: 666-674.

Muly EC, Allen P, Mazloom M, Aranbayeva Z, Greenfield AT, Greengard P. 2004a. Subcellular distribution of neurabin immunolabeling in primate prefrontal cortex: Comparison with spinophilin. Cereb Cortex 14: 1398-1407.

Muly EC, Smith Y, Allen P, Greengard P. 2004b. Subcellular distribution of spinophilin immunolabeling in primate prefrontal cortex: Localization to and within dendritic spines. J Comp Neurol 469: 185-197.

Naisbitt S, Kim E, Weinberg RJ, Rao A, Yang FC, Craig AM Sheng M. 1997. Characterization of guanylate kinase-associated protein, a postsynaptic density protein at excitatory synapses that interacts directly with postsynaptic density-95/synapse-associated protein 90. J Neurosci 17: 5687-5696.

Naisbitt S, Kim E, Tu JC, Xiao B, Sala C, Valtschanoff J, Weinberg RJ, Worley PF, Sheng M. 1999. Shank, a novel family of postsynaptic density proteins that binds to the NMDA receptor/PSD-95/GKAP complex and cortactin. Neuron 23: 569-582.

Naisbitt S, Valtschanoff J, Allison DW, Sala C, Kim E, Craig AM, Weinberg RJ, Sheng M. 2000. Interaction of the postsynaptic density-95/guanylate kinase domain-associated protein complex with a light chain of myosin- $\mathrm{V}$ and dynein. J Neurosci 20: 4524-4534.

Needleman LA, Liu XB, El-Sabeawy F, Jones EG, McAllister AK. 2010. MHC class I molecules are present both preand postsynaptically in the visual cortex during postnatal development and in adulthood. Proc Natl Acad Sci 107: 16999-17004.

Neuhoff H, Sassoe-Pognetto M, Panzanelli P, Maas C, Witke W, Kneussel M. 2005. The actin-binding protein profilin I is localized at synaptic sites in an activity-regulated manner. Eur J Neurosci 21: 15-25.

Nicholson DA, Geinisman Y. 2009. Axospinous synaptic subtype-specific differences in structure, size, ionotropic receptor expression, and connectivity in apical dendritic regions of rat hippocampal CA1 pyramidal neurons. $J$ Comp Neurol 512: 399-418.

Niethammer M, Valtschanoff JG, Kapoor TM, Allison DW, Weinberg RJ, Craig AM, Sheng M. 1998. CRIPT, a novel postsynaptic protein that binds to the third PDZ domain of PSD-95/SAP90. Neuron 20: 693-707.

Nishioka H, Mizoguchi A, Nakanishi H, Mandai K, Takahashi K, Kimura K, Satoh-Moriya A, Takai Y. 2000. Localization of l-afadin at puncta adhaerentia-like junctions 
between the mossy fiber terminals and the dendritic trunks of pyramidal cells in the adult mouse hippocampus. J Comp Neurol 424: 297-306.

Notomi T, Shigemoto R. 2004. Immunohistochemical localization of Ih channel subunits, $\mathrm{HCN} 1-4$, in the rat brain. $J$ Comp Neurol 471: 241-276.

Nusser Z. 2000. AMPA and NMDA receptors: Similarities and differences in their synaptic distribution. Curr Opin Neurobiol 10: 337-341.

Nusser Z, Sieghart W, Benke D, Fritschy JM, Somogyi P. 1996. Differential synaptic localization of two major $\gamma$ aminobutyric acid type A receptor $\alpha$ subunits on hippocampal pyramidal cells. Proc Natl Acad Sci 93: 1193911944.

Nusser Z, Cull-Candy S, Farrant M. 1997. Differences in synaptic $\mathrm{GABA}_{\mathrm{A}}$ receptor number underlie variation in GABA mini amplitude. Neuron 19: 697-709.

Nusser Z, Lujan R, Laube G, Roberts JD, Molnar E, Somogyi P. 1998. Cell type and pathway dependence of synaptic AMPA receptor number and variability in the hippocampus. Neuron 21: 545-559.

Nyiri G, Freund TF, Somogyi P. 2001. Input-dependent synaptic targeting of $\alpha_{2}$-subunit-containing $\mathrm{GABA}_{\mathrm{A}}$ receptors in synapses of hippocampal pyramidal cells of the rat. Eur J Neurosci 13: 428-442.

Nyiri G, Cserep C, Szabadits E, Mackie K, Freund TF. 2005 CB1 cannabinoid receptors are enriched in the perisynaptic annulus and on preterminal segments of hippocampal GABAergic axons. Neurosci 136: 811-822.

O’Brien ET, Salmon ED, Erickson HP. 1997. How calcium causes microtubule depolymerization. Cell Motil Cytoskeleton 36: 125-135.

O’Brien RJ, Xu D, Petralia RS, Steward O, Huganir RL, Worley P. 1999. Synaptic clustering of AMPA receptors by the extracellular immediate-early gene product Narp. Neuron 23: $309-323$.

Ostroff LE, Fiala JC, Allwardt B, Harris KM. 2002. Polyribosomes redistribute from dendritic shafts into spines with enlarged synapses during LTP in developing rat hippocampal slices. Neuron 35: 535-545.

Ostroff LE, Cain CK, Bedont J, Monfils MH, LeDoux JE. 2010. Fear and safety learning differentially affect synapse size and dendritic translation in the lateral amygdale. Proc Natl Acad Sci 107: 9418-9423.

Otmakhov N, Tao-Cheng JH, Carpenter S, Asrican B, Dosemeci A, Reese TS, Lisman J. 2004. Persistent accumulation of calcium/calmodulin-dependent protein kinase II in dendritic spines after induction of NMDA receptordependent chemical long-term potentiation. J Neurosci 24: 9324-9331.

Ottersen OP, Landsend AS. 1997. Organization of glutamate receptors at the synapse. Eur J Neurosci 9: 2219-2224.

Palay SL, Chan-Palay V. 1974. Cerebellar cortex: Cytology and organization. Springer-Verlag, New York.

Palay SL, Palade GE. 1955. The fine structure of neurons. J Biophys Biochem Cytol 1: 69-88.

Park M, Salgado JM, Ostroff L, Helton TD, Robinson CG Harris KM, Ehlers MD. 2006. Plasticity-induced growth of dendritic spines by exocytic trafficking from recycling endosomes. Neuron 52: 817-830.
Penzes P, Cahill ME, Jones KA, Srivastava DP. 2008. Convergent CaMK and RacGEF signals control dendritic structure and function. Trends Cell Biol 18: 405-413.

Peters A, Palay SL, Webster HD. 2003. The fine structure of the nervous system: The neurons and supporting cells. Saunders, Philadelphia.

Petersen JD, Chen X, Vinade L, Dosemeci A, Lisman JE, Reese TS. 2003. Distribution of postsynaptic density (PSD)-95 and $\mathrm{Ca}^{2+} /$ calmodulin-dependent protein kinase II at the PSD. J Neurosci 23: 11270-11278.

Petrak LJ, Harris KM, Kirov SA. 2005. Synaptogenesis on mature hippocampal dendrites occurs via filopodia and immature spines during blocked synaptic transmission. J Comp Neuro 484: 183-190.

Petralia RS, Wang YX, Sans N, Worley PF, Hammer JA III, Wenthold RJ. 2001. Glutamate receptor targeting in the postsynaptic spine involves mechanisms that are independent of myosin Va. Eur J Neurosci 13: 1722-1732.

Petralia RS, Sans N, Wang YX, Wenthold RJ. 2005. Ontogeny of postsynaptic density proteins at glutamatergic synapses. Mol Cell Neurosci 29: 436-452.

Petralia RS, Wang YX, Hua F, Yi Z, Zhou A, Ge L, Stephenson FA, Wenthold RJ. 2010. Organization of NMDA receptors at extrasynaptic locations. Neurosci 167: 68-87.

Pfenninger K, Akert K, Moor H, Sandri C. 1972. The fine structure of freeze-fractured presynaptic membranes. $J$ Neurocytol 1: 129-149.

Phillips GR, Tanaka H, Frank M, Elste A, Fidler L, Benson DL, Colman DR. 2003. $\gamma$-Protocadherins are targeted to subsets of synapses and intracellular organelles in neurons. J Neurosci 23: 5096-5104.

Pierce JP, van Leyen K, McCarthy JB. 2000. Translocation machinery for synthesis of integral membrane and secretory proteins in dendritic spines. Nat Neurosci 3: 311-313.

Pierce JP, Mayer T, McCarthy JB. 2001. Evidence for a satellite secretory pathway in neuronal dendritic spines. Curr Biol 11: 351-355.

Pinard A, Seddik R, Bettler B. 2010. GABA $\mathrm{B}_{\mathrm{B}}$ receptors: Physiological functions and mechanisms of diversity. $A d v$ Pharmacol 58: 231-255.

Popov VI, Medvedev NI, Patrushev IV, Ignat'ev DA, Morenkov ED, Stewart MG. 2007. Reversible reduction in dendritic spines in CAl or rat and ground squirrel subjected to hypothermia-normothermia in vivo: A three-dimensional electron microscope study. Neuroscience 149: 549-560.

Puente N, Mendizabal-Zubiaga J, Elezgarai I, Reguero L, Buceta I, Grandes P. 2010. Precise localization of the voltagegated potassium channel subunits Kv3.1b and Kv3.3 revealed in the molecular layer of the rat cerebellar cortex by a pre-embedding immunogold method. Histochem Cell Biol 134: 403-409.

Qu L, Akbergenova Y, Hu Y, Schikorski T. 2009. Synapse-tosynapse variation in mean synaptic vesicle size and its relationship with synaptic morphology and function. $J$ Comp Neurol 514: 343-352.

Racca C, Stephenson FA, Streit P, Roberts JD, Somogyi P. 2000. NMDA receptor content of synapses in stratum radiatum of the hippocampal CA1 area. J Neurosci 20: $2512-2522$. 
K.M. Harris and R.J. Weinberg

Racz B, Weinberg RJ. 2004. The subcellular organization of cortactin in hippocampus. J Neurosci 24: 10310-10317.

Racz B, Weinberg RJ. 2006. Spatial organization of cofilin in dendritic spines. Neurosci 138: 447-456.

Racz B, Weinberg RJ. 2008. Organization of the Arp2/3 complex in hippocampal spines. J Neurosci 28: $5654-$ 5659.

Racz B, Blanpied TA, Ehlers MD, Weinberg RJ. 2004. Lateral organization of endocytic machinery in dendritic spines. Nat Neurosci 7: 917-918.

Riad M, Garcia S, Watkins KC, Jodoin N, Doucet É, Langlois X, El Mestikawy S, Hamon M, Descarries L. 2000. Somatodendritic localization of 5-HT1A and preterminal axonal localization of 5-HT1B serotonin receptors in adult rat brain. J Comp Neurol 417: 181-194.

Richards DA, Mateos JM, Hugel S, De Paola V, Caroni P, Gahwiler BH, McKinney RA. 2005. Glutamate induces the rapid formation of spine head protrusions in hippocampal slice cultures. Proc Natl Acad Sci 102: 6166-6171.

Rizzoli SO, Jahn R. 2007. Kiss-and-run, collapse and "readily retrievable" vesicles. Traffic 8: 1137-1144.

Rollenhagen A, Satzler K, Rodriguez EP, Jonas P, Frotscher M, Lubke JH. 2007. Structural determinants of transmission at large hippocampal mossy fiber synapses. J Neurosci 27: 10434-10444.

Royle SJ, Lagnado L. 2010. Clathrin-mediated endocytosis at the synaptic terminal: Bridging the gap between physiology and molecules. Traffic 11: 1489-1497.

Rubio ME, Soto F. 2001. Distinct localization of P2X receptors at excitatory postsynaptic specializations. J Neurosci 21: 641-653.

Sakagami H, Sanda M, Fukaya M, Miyazaki T, Sukegawa J, Yanagisawa T, Suzuki T, Fukunaga K, Watanabe M, Kondo K. 2008. IQ-ArfGEF/BRAG1 is a guanine nucleotide exchange factor for Arf6 that interacts with PSD-95 at postsynaptic density of excitatory synapses. Neurosci Res 60: 199-212.

Sanda M, Kamata A, Katsumata O, Fukunaga K, Watanabe M, Kondo H, Sakagami H. 2009. The postsynaptic density protein, IQ-ArfGEF/BRAG1, can interact with IRSp53 through its proline-rich sequence. Brain Res 1251: 7-15.

Sans N, Petralia RS, Wang YX, Blahos J, Hell JW, Wenthold RJ. 2000. A developmental change in NMDA receptorassociated proteins at hippocampal synapses. J Neurosci 20: $1260-1271$.

Schikorski T, Stevens CF. 1997. Quantitative ultrastructural analysis of hippocampal excitatory synapses. J Neurosci 17: $5858-5867$.

Schikorski T, Stevens CF. 1999. Quantitative fine-structural analysis of olfactory cortical synapses. Proc Natl Acad Sci 96: 4107-4112.

Schikorski T, Stevens CF. 2001. Morphological correlates of functionally defined synaptic vesicle populations. Nat Neurosci 4: 391-395.

Schnell E, Sizemore M, Karimzadegan S, Chen L, Bredt DS, Nicoll RA. 2002. Direct interactions between PSD-95 and stargazin control synaptic AMPA receptor number. Proc Natl Acad Sci 99: 13902-13907.

Schoch S, Gundelfinger ED. 2006. Molecular organization of the presynaptic active zone. Cell Tissue Res 326: 379-391.
Seabold GK, Wang PY, Chang K, Wang CY, Wang YX, Petralia RS, Wenthold RJ. 2008. The SALM family of adhesionlike molecules forms heteromeric and homomeric complexes. J Biol Chem 283: 8395-8405.

Sebeo J, Hsiao K, Bozdagi O, Dumitriu D, Ge Y, Zhou Q, Benson DL. 2009. Requirement for protein synthesis at developing synapses. J Neurosci 29: 9778-9793.

Serwanski DR, Miralles CP, Christie SB, Mehta AK, Li X, De Blas AL. 2006. Synaptic and nonsynaptic localization of $\mathrm{GABA}_{\mathrm{A}}$ receptors containing the $\alpha 5$ subunit in the rat brain. J Comp Neurol 499: 458-470.

Shapiro L, Love J, Colman DR. 2007. Adhesion molecules in the nervous system: Structural insights into function and diversity. Annu Rev Neurosci 30: 451-474.

Sheng M, Kim E. 2011. The postsynaptic organization of synapses. Cold Spring Harb Perspect Biol 3: a005678.

Shepherd GM. 1995. Foundations of the neuron doctrine. Oxford University Press, New York.

Shepherd GM, Harris KM. 1998. Three-dimensional structure and composition of $\mathrm{CA} 3 \rightarrow \mathrm{CA} 1$ axons in rat hippocampal slices: Implications for presynaptic connectivity and compartmentalization. J Neurosci 18: 8300-8310.

Shin H, Wyszynski M, Huh KH, Valtschanoff JG, Lee JR, Ko J, Streuli M, Weinberg RJ, Sheng M, Kim E. 2003. Association of the kinesin motor KIF1A with the multimodular protein liprin- $\alpha$. J Biol Chem 278: 11393-11401.

Shinohara Y, Hirase H, Watanabe M, Itakura M, Takahashi M, Shigemoto R. 2008. Left-right asymmetry of the hippocampal synapses with differential subunit allocation of glutamate receptors. Proc Natl Acad Sci 105: 19498 19503.

Siksou L, Rostaing P, Lechaire JP, Boudier T, Ohtsuka T, Fejtova A, Kao HT, Greengard P, Gundelfinger ED, Triller A, et al. 2007. Three-dimensional architecture of presynaptic terminal cytomatrix. J Neurosci 27: 6868-6877.

Siksou L, Triller A, Marty A. 2009. An emerging view of presynaptic structure from electron microscopic studies. $J$ Neurochem 108: 1336-1342.

Song JY, Ichtchenko K, Sudhof TC, Brose N. 1999. Neuroligin 1 is a postsynaptic cell-adhesion molecule of excitatory synapses. Proc Natl Acad Sci 96: 1100-1105.

Sorra KE, Mishra A, Kirov SA, Harris KM. 2006. Dense core vesicles resemble active-zone transport vesicles and are diminished following synaptogenesis in mature hippocampal slices. Neurosci 141: 2097-2106.

Spacek J, Harris KM. 1997. Three-dimensional organization of smooth endoplasmic reticulum in hippocampal CA1 dendrites and dendritic spines of the immature and mature rat. J Neurosci 17: 190-203.

Spacek J, Harris KM. 1998. Three-dimensional organization of cell adhesion junctions at synapses and dendritic spines in area CAl of the rat hippocampus. J Comp Neurol 393: 58-68.

Spacek J, Harris KM. 2004. Trans-endocytosis via spinules in adult rat hippocampus. J Neurosci 24: 4233-4241.

Spacek J, Hartmann M. 1983. Three-dimensional analysis of dendritic spines. I. Quantitative observations related to dendritic spine and synaptic morphology in cerebral and cerebellar cortices. Anat Embryol (Berl) 167: 289310 . 
Srivastava S, Osten P, Vilim FS, Khatri L, Inman G, States B, Daly C, DeSouza S, Abagyan R, Valtschanoff JG, et al. 1998. Novel anchorage of GluR2/3 to the postsynaptic density by the AMPA receptor-binding protein ABP. Neuron 21: 581-591.

Steward O, Reeves TM. 1988. Protein-synthetic machinery beneath postsynaptic sites on CNS neurons: Association between polyribosomes and other organelles at the synaptic site. J Neurosci 8: 176-184.

Stewart MG, Davies HA, Sandi C, Kraev IV, Rogachevsky VV, Peddie CJ, Rodriguez JJ, Cordero MI, Donohue HS, Gabbott PLA, et al. 2005. Stress suppresses and learning induces plasticity in CA3 of rat hippocampus: A three-dimensional ultrastructural study of thorny excrescences and their postsynaptic densities. Neuroscience 131: 4354 .

Steward O, Schuman EM. 2003. Compartmentalized synthesis and degradation of proteins in neurons. Neuron 40: $347-359$.

Sudhof TC. 1995. The synaptic vesicle cycle: A cascade of protein-protein interactions. Nature 375: 645-653.

Sudhof TC. 2004. The synaptic vesicle cycle. Annu Rev Neurosci 27: 509-547.

Svitkina T, Lin WH, Webb DJ, Yasuda R, Wayman GA, Van AL, Soderling SH. 2010. Regulation of the postsynaptic cytoskeleton: Roles in development, plasticity, and disorders. J Neurosci 30: 14937-14942.

Swulius MT, Kubota Y, Forest A, Waxham MN. 2010. Structure and composition of the postsynaptic density during development. J Comp Neurol 518: 4243-4260.

Tada T, Sheng M. 2006. Molecular mechanisms of dendritic spine morphogenesis. Curr Opin Neurobiol 16: 95-101.

Takamori S, Holt M, Stenius K, Lemke EA, Gronborg M, Riedel D, Urlaub H, Schenck S, Brugger B, Ringler P, et al. 2006. Molecular anatomy of a trafficking organelle. Cell 127: 831-846.

Takumi Y, Ramirez-Leon V, Laake P, Rinvik E, Ottersen OP. 1999. Different modes of expression of AMPA and NMDA receptors in hippocampal synapses. Nat Neurosci 2: $618-624$.

Tamaru Y, Nomura S, Mizuno N, Shigemoto R. 2001. Distribution of metabotropic glutamate receptor mGluR3 in the mouse CNS: Differential location relative to preand postsynaptic sites. Neuroscience 106: 481-503.

Taniguchi H, Gollan L, Scholl FG, Mahadomrongkul V, Dobler E, Limthong N, Peck M, Aoki C, Scheiffele P. 2007. Silencing of neuroligin function by postsynaptic neurexins. J Neurosci 27: 2815-2824.

Tao-Cheng JH. 2006. Activity-related redistribution of presynaptic proteins at the active zone. Neuroscience 141: 1217-1224.

Tao-Cheng JH. 2007. Ultrastructural localization of active zone and synaptic vesicle proteins in a preassembled multi-vesicle transport aggregate. Neuroscience 150: 575-584.

Tao-Cheng JH, Dosemeci A, Winters CA, Reese TS. 2006. Changes in the distribution of calcium calmodulin-dependent protein kinase II at the presynaptic bouton after depolarization. Brain Cell Biol 35: 117-124.

Tao-Cheng JH, Gallant PE, Brightman MW, Dosemeci A, Reese TS. 2007. Structural changes at synapses after de- layed perfusion fixation in different regions of the mouse brain. J Comp Neurol 501: 731-740.

Tatsuoka H, Reese TS. 1989. New structural features of synapses in the anteroventral cochlear nucleus prepared by direct freezing and freeze-substitution. J Comp Neurol 290: 343-357.

Togashi H, Sakisaka T, Takai Y. 2009. Cell adhesion molecules in the central nervous system. Cell Adh Migr 3: 29-35.

Tolias KF, Bikoff JB, Burette A, Paradis S, Harrar D, Tavazoie S, Weinberg RJ, Greenberg ME. 2005. The Rac1-GEF Tiam1 couples the NMDA receptor to the activitydependent development of dendritic arbors and spines. Neuron 45: 525-538.

Torrealba F, Carrasco MA. 2004. A review on electron microscopy and neurotransmitter systems. Brain Res Brain Res Rev 47: 5-17.

Tremblay ME, Riad M, Bouvier D, Murai KK, Pasquale EB, Descarries L, Doucet G. 2007. Localization of EphA4 in axon terminals and dendritic spines of adult rat hippocampus. J Comp Neurol 501: 691-702.

Tretter VS, Moss J. 2008. $\mathrm{GABA}_{\mathrm{A}}$ receptor dynamics and constructing GABAergic synapses. Front Mol Neurosci 1: 7 .

Uchida N, Honjo Y, Johnson KR, Wheelock MJ, Takeichi M. 1996. The catenin/cadherin adhesion system is localized in synaptic junctions bordering transmitter release zones. J Cell Biol 135: 767-779.

Valtschanoff JG, Weinberg RJ. 2001. Laminar organization of the NMDA receptor complex within the postsynaptic density. J Neurosci 21: 1211-1217.

Valtschanoff JG, Burette A, Davare MA, Leonard AS, Hell JW, Weinberg RJ. 2000. SAP97 concentrates at the postsynaptic density in cerebral cortex. Eur J Neurosci 12: 3605-3614.

van der Want JJ, Nunes Cardozo JJ, Vrensen G. 1984. Variations in presynaptic grid size in the granular and molecular layer of the cerebellar cortex of the cat. I. A quantitative ultrastructural study on semithin E-PTA sections. Brain Res 307: 247-254.

Walton PD, Airey JA, Sutko JL, Beck CF, Mignery GA, Sudhof TC, Deerinck TJ, Ellisman MH. 1991. Ryanodine and inositol trisphosphate receptors coexist in avian cerebellar Purkinje neurons. J Cell Biol 113: 1145-1157.

Weisenberg RC. 1972. Microtubule formation in vitro in solutions containing low calcium concentrations. Science 177: 1104-1105.

Weisenberg RC, Deery WJ. 1981. The mechanism of calciuminduced microtubule disassembly. Biochem Biophys Res Commun 102: 924-931.

Westrum LE, Gray EG. 1977. Microtubules associated with postsynaptic "thickenings." J Neurocytol 6: 505-518.

Westrum LE, Jones DH, Gray EG, Barron J. 1980. Microtubules, dendritic spines and spine apparatuses. Cell Tissue Res 208: 171-181.

Willig KI, Rizzoli SO, Westphal V, Jahn R, Hell SW. 2006. STED microscopy reveals that synaptotagmin remains clustered after synaptic vesicle exocytosis. Nature 440: 935-939. 
K.M. Harris and R.J. Weinberg

Wilson CJ, Groves PM, Kitai ST, Linder JC. 1983. Three dimensional structure of dendritic spines in rat striatum. J Neurosci 3: 383-398.

Woo J, Kwon SK, Kim E. 2009. The NGL family of leucinerich repeat-containing synaptic adhesion molecules. $\mathrm{Mol}$ Cell Neurosci 42: 1-10.

Wyszynski M, Kharazia V, Shanghvi R, Rao A, Beggs AH, Craig AM, Weinberg R, Sheng M. 1998. Differential regional expression and ultrastructural localization of $\alpha$-actinin-2, a putative NMDA receptor-anchoring protein, in rat brain. J Neurosci 18: 1383-1392.

Wyszynski M, Valtschanoff JG, Naisbitt S, Dunah AW, Kim E, Standaert DG, Weinberg R, Sheng M. 1999. Association of AMPA receptors with a subset of glutamate receptor-interacting protein in vivo. J Neurosci 19: 6528-6537.

Wyszynski M, Kim E, Dunah AW, Passafaro M, Valtschanoff JG, Serra-Pages C, Streuli M, Weinberg RJ, Sheng M. 2002. Interaction between GRIP and liprin- $\alpha /$ SYD2 is required for AMPA receptor targeting. Neuron 34: 39-52.

Xu D, Hopf C, Reddy R, Cho RW, Guo L, Lanahan A, Petralia RS, Wenthold RJ, O’Brien RJ, Worley P. 2003. Narp and NP1 form heterocomplexes that function in developmental and activity-dependent synaptic plasticity. Neuron 39: 513-528.

Xu-Friedman MA, Harris KM, Regehr WG. 2001. Threedimensional comparison of ultrastructural characteristics at depressing and facilitating synapses onto cerebellar Purkinje cells. J Neurosci 21: 6666-6672.

Yamada A, Irie K, Deguchi-Tawarada M, Ohtsuka T, Takai Y. 2003. Nectin-dependent localization of synaptic scaffold- ing molecule (S-SCAM) at the puncta adherentia junctions formed between the mossy fibre terminals and the dendrites of pyramidal cells in the CA3 area of the mouse hippocampus. Genes Cells 8: 985-994.

Yankova M, Hart SA, Woolley CS. 2001. Estrogen increases synaptic connectivity between single presynaptic inputs and multiple postsynaptic CA1 pyramidal cells: A serial electron-microscopic study. Proc Natl Acad Sci 98: 3525-3530.

Yu W, Charych EI, Serwanski DR, Li RW, Ali R, Bahr BA, De Blas AL. 2008. Gephyrin interacts with the glutamate receptor interacting protein 1 isoforms at GABAergic synapses. J Neurochem 105: 2300-2314.

Zhai RG, Vardinon-Friedman H, Cases-Langhoff C, Becker B, Gundelfinger ED, Ziv NE, Garner CC. 2001. Assembling the presynaptic active zone: A characterization of an active one precursor vesicle. Neuron 29: 131-143.

Zhao HM, Wenthold RJ, Petralia RS. 1998. Glutamate receptor targeting to synaptic populations on Purkinje cells is developmentally regulated. J Neurosci 18: 5517-5528.

Zipursky SL, Sanes JR. 2010. Chemoaffinity revisited: Dscams, protocadherins, and neural circuit assembly. Cell 143: 343-353.

Ziv NE, Garner CC. 2004. Cellular and molecular mechanisms of presynaptic assembly. Nat Rev Neurosci 5: 385399.

Zuber B, Nikonenko I, Klauser P, Muller D, Dubochet J. 2005. The mammalian central nervous synaptic cleft contains a high density of periodically organized complexes. Proc Natl Acad Sci 102: 19192-19197. 


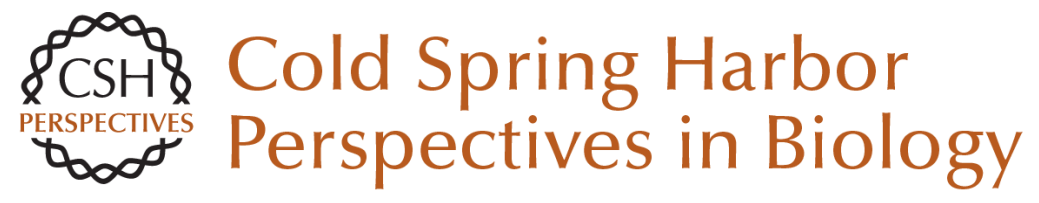

\section{Ultrastructure of Synapses in the Mammalian Brain}

Kristen M. Harris and Richard J. Weinberg

Cold Spring Harb Perspect Biol 2012; doi: 10.1101/cshperspect.a005587 originally published online February 21, 2012

\section{Subject Collection The Synapse}

Studying Signal Transduction in Single Dendritic Spines Ryohei Yasuda

Synaptic Vesicle Pools and Dynamics AbdulRasheed A. Alabi and Richard W. Tsien

Synapses and Memory Storage Mark Mayford, Steven A. Siegelbaum and Eric $R$. Kandel

Synapses and Alzheimer's Disease Morgan Sheng, Bernardo L. Sabatini and Thomas C. Südhof

\section{Synaptic Cell Adhesion}

Markus Missler, Thomas C. Südhof and Thomas Biederer

Synaptic Dysfunction in Neurodevelopmental Disorders Associated with Autism and Intellectual Disabilities

Huda Y. Zoghbi and Mark F. Bear

The Postsynaptic Organization of Synapses Morgan Sheng and Eunjoon Kim

Presynaptic LTP and LTD of Excitatory and Inhibitory Synapses

Pablo E. Castillo
Synaptic Vesicle Endocytosis

Yasunori Saheki and Pietro De Camilli

Short-Term Presynaptic Plasticity Wade G. Regehr

NMDA Receptor-Dependent Long-Term

Potentiation and Long-Term Depression

(LTP/LTD) Christian Lüscher and Robert C. Malenka

Ultrastructure of Synapses in the Mammalian

Brain Kristen M. Harris and Richard J. Weinberg

Calcium Signaling in Dendritic Spines Michael J. Higley and Bernardo L. Sabatini

Synaptic Neurotransmitter-Gated Receptors Trevor G. Smart and Pierre Paoletti

Synaptic Vesicle Exocytosis

Thomas C. Südhof and Josep Rizo

Vesicular and Plasma Membrane Transporters for Neurotransmitters

Randy D. Blakely and Robert H. Edwards

For additional articles in this collection, see http://cshperspectives.cshlp.org/cgi/collection/

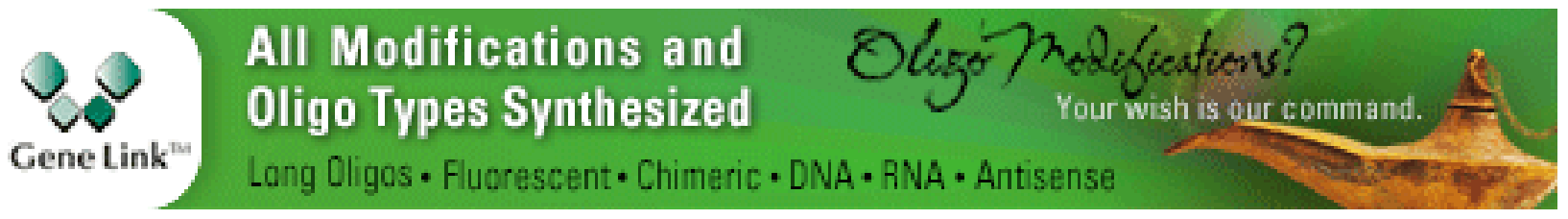

